\title{
TO LEND OR NOT TO LEND-THAT SHOULD \\ NOT BE THE QUESTION: THE \\ UNCERTAINTIES OF LENDER \\ LIABILITY UNDER CERCLA
}

\author{
MiChaEL I. GreENBERG \\ DAVID M. SHAW
}

\section{INTRODUCTION}

Uncertainty and confusion pervade environmental liability standards for lenders under the Comprehensive Environmental Response, Compensation and Liability Act of 1980 (CERCLA). ${ }^{1}$ As a result, lending practices have become distorted so that lenders cannot simultaneously minimize both their environmental and financial risks. In a hearing on the issue before the House Committee on Small Business, Deinocratic Representative John J. LaFalce of New York summed up the perplexing position of lenders: ${ }^{2}$

There is no certainty to the potential lender. The lender says: "What ... is EPA going to do, what are the courts going to do? I do not know. Why should I create a headache for myself? ... [I] do not know what the costs [for the cleanup of hazardous waste] are going to be, so if [I] make a $\$ 10,000$ loan [I] might be hable for a $\$ 2$ million cleanup.["] $]^{3}$

Much of the lenders' uncertainty and confusion arises from the various and often conflicting interpretations of CERCLA's secured creditor exeinption, ${ }^{4}$ which excludes from CERCLA's definition of "owner" or "operator" any person "wlio, witlout participating in the management

1. Pub. L. No. 96-510, 94 Stat. 2767 (codified as amended at 42 U.S.C. $\$ \S 9601-9675$ (1988)). CERCLA was amended by the Superfund Amendments and Reauthorization Act of 1986 (SARA), Pub. L. No. 99-499, 100 Stat. 1613. CERCLA functions within an extensive federal environmental scheme to identify and clean up hazardous waste sites posing a danger to the public, id. $\$ \S 103-106$, 42 U.S.C. $\$ \S 9603-9606$, to impose hability to recover clean up expenses, id. $\S 107(\mathrm{a}), 42$ U.S.C. $\S 9607(\mathrm{a})$, and to provide for the recovery of damages to natural resources, $i d$. $\S \S 107(\mathrm{a})(4)(\mathrm{C})$, (f), 42 U.S.C. $\$ \S 9607(a)(4)(C),(f)$.

2. Throughout this Note, secured creditors are referred to interchangeably as either lenders or secured creditors.

3. Lender Liability Under Superfund: Hearing Before the House Comm. on Small Business, 101st Cong., 1st Sess. 8-9 (1989) [hereinafter Small Business Hearing] (statement by Rep. John J. LaFalce during testimony of Glenn L. Unterberger, Environmental Protection Agency (EPA)). In United States v. Maryland Bank \& Trust Co., 632 F. Supp. 573 (D. Md. 1986), for instance, over $\$ 400,000$ in cleanup costs were imposed on a lender who loaned the facility only $\$ 335,000$.

4. CERCLA $\S 101(20)(A), 42$ U.S.C. $\S 9601(20)(A)$. 
of a vessel or facility, holds indicia of ownership primarily to protect his security interest in the vessel or facility."5 If satisfied, the exemption protects a lender from CERCLA hability as an owner. The source of the confusion, however, is not limited to the judiciary-Congress has aborted numerous attempts to clarify the standards, and the executive branch has exploited ambiguities in the law to satisfy shifting political tides.

Subsequent to Representative LaFalce's comments, the Court of Appeals for the Eleventh Circuit, in United States v. Fleet Factors Corp. ${ }^{6}$ and the Court of Appeals for the Ninth Circuit, in In re Bergsoe Metals Corp. ${ }^{7}$ atteinpted to square conflicting national policies with CERCLA's ambiguous language, legislative history, and complex economic and environmental concerns. In the wake of Congress's failure to set a clear national policy, these courts attempted to discover an appropriate balance between the competing imterests, but instead inanaged only to create unstable, inconsistent, and obscure legal precedent, thereby exacting a fearful yet justified reaction from secured creditors. ${ }^{8}$ Under the standard adopted by the Fleet Factors court, a lender could arguably incur liability simply by having been in a position to control the borrower's hazardous waste decisions, whether or not the lender actually exercised such control.

Lenders are not alone in suffering the consequences of the trend toward increasing lender hability. Because lenders are increasingly shying away from enviroumentally risky loans, businesses that require funds to begin new enterprises and to cure existing environinental hazards also

5. Id.; see also Resource Conservation and Recovery Act of 1984 (RCRA), Pub. L. No. 98616, § 601(a), 98 Stat. 3221,3279 (codified as amended at 42 U.S.C. $\$ 6991$ b(h)(9) (1988)) (excluding from RCRA's definition of "owner" any person "who, without participating in the management of an underground storage tank and otherwise not engaged in petroleum production, refining, and marketing, holds indicia of ownership primarily to protect the owner's security interest in the tank").

6. 901 F.2d 1550 (11th Cir. 1990), cert. denied, 111 S. Ct. 752 (1991).

7. 910 F.2d 668 (9th Cir. 1990).

8. See, e.g., Richard H. Mays, Secured Creditors and Superfund: Avoiding the Liability Net, 20 Env't Rep. (BNA) 609 (July 28, 1989) ("The liability net created by CERCLA is like a inile-long net behind a modern fishing trawler: it is wide, deep, and dangerous to anything that gets caught up in it."); Alan P. Vollmann, Double Jeopardy: Lender Liability Under Superfund, 16 REAL EsT. L.J. 3, 3 (1987) ("Compliance with environmental laws can no longer be merely a routine checkoff on a closing agenda; it must be a major factor in determiming whether a loan should be inade."). But see Amy T. Phillips, Environmental Groups Argue EPA's Proposed Lender Liability Rule Is Sweetheart Deal for Lenders, 57 Banking Rep. (BNA) No. 10, at 373 (Sept. 9, 1991) (reporting Chemical Manufacturers Association coinplaint that " virtually any other single-industry group could establish a more compelling record of superfund's financial inpact . . . ' "); Randall J. Burke, Note, Much Ado About Lending: Continuing Vitality of the Fleet Faetors Decision, 80 GEo. L.J. 809, 812-13 (1992) (praising the Fleet Factors decision). 
feel the impact of broader lender hability. ${ }^{9}$ Ironically, this impact does not differentiate between financings that would benefit the environment and those that would "price out" environmentally risky enterprises, ${ }^{10}$ and ignores that financially impaired firms niay be more likely to evade environmental laws. Thus, the prevailing law, by tightening the supply of funds to such firms through the threat and imposition of hability on the lender, can actually aggravate environmental damage.

CERCLA's broad hability provisions impose strict hability ${ }^{11}$ on present owners and operators, ${ }^{12}$ and also on any person who was an owner or operator at the time of any release of hazardous waste: ${ }^{13} \mathrm{Be}-$ cause owners are autoniatically hable, it is important to consider how "ownership" is defined by state common law. In states that utilize a title theory for mortgages (as opposed to a hen theory), the mortgagees (lenders) hold actual title to the secured property and thus can be considered owners of the property. ${ }^{14}$ The legislative history of the exemption and, in particular, the amendments to the exemption's original language prior to passage strongly indicate that "Congress intended [the exeinption] to exclude these common law title mortgagees froin the definition of 'owner' since title was in their hands only by operation of the common law."15 CERCLA would thereby place "title" inortgagees on the same footing with "hen" mortgagees.16 Despite the judicial attention given to CERCLA's lender hability provisions, only two federal courts have

9. See infra note 221 and accompanying text; Small Business Hearing, supra note 3, at 87 (statement of Michael Dore, Esq.) ("[Banks have been] extremely hesitant in extending loans to enterprises engaged in environmentally sensitive operations ...."); see also John M. Campbell, Jr., Lender Liability Under Superfund: Deep Pockets Don't Always Yield Free Goods, The ENvTL. F. 5, 6 (Jan./Feb. 1989) (lenders are coucerned with two forms of risk stemming from Superfund hability: credit risk and Superfund costs).

10. Under Fleet Factors, 901 F.2d at 1550, for example, if a secured loan is made to fund the cleanup of a hazardons waste site (which all would agree is a desirable step consistent with CERCLA), the lender may nevertheless become jointly and severally hable for the full cost of the cleanup.

11. See, eg., United States v. Monsanto Co., 858 F.2d 160, 167 \& n.11 (4th Cir. 1988), cert. denied, 490 U.S. 1106 (1989); Tanglewood E. Honieowners v. Charles-Thomas, Inc., 849 F.2d 1568, 1572 (5th Cir. 1988).

12. CERCLA § 107(a)(1)-(2), 42 U.S.C. § 9607(a)(1)-(2).

13. See id. $\S 107(a), 42$ U.S.C. $\$ 9607(a)$; infra notes $21-27$ and accompanying text.

14. In a majority of states, a mortgage is regarded as nothing more than a hen on property to secure a debt which does not transfer real title to the nortgagee. See 59 C.J.S. Mortgages $§ 1(b)(1)$ (1949 \& Supp. 1991) (citing cases). A minority of states follow the common law theory of mortgages, under which actual legal title to the property is transferred to the mortgagee as security for the loan. See id. \& $1(b)(2)$ (citing cases).

15. United States v. Maryland Bank \& Trust Co., 632 F. Supp. 573, 579 (D. Md. 1986).

16. This interpretation of CERCLA's exemption will hereinafter be referred to as the "title/lien theory." 
adopted this interpretation, ${ }^{17}$ which this Note argues is the only one consistent with CERCLA's overall structure and the exeinption's legislative history.

The courts that have departed from this title/lien theory interpretation have engaged in wishful thinking. Given CERCLA's ambiguous language and the perceived mequities and inefficiencies of a literal apphcation of the exemption, some courts have molded the exeinption to address lender liability issues in ways that the courts deeined appropriate. However, as Judge Newcomer noted in United States v. Mirabile, ${ }^{18}$ probably the most pro-lender decision of all the lower court cases, while enhanced lender hability might promote responsible hazardous waste practices, "[t]he consideration of such pohicy matters, and the decision as to the imposition of such hability, ... lies with Congress." 19

Even though several environmental groups oppose narrowing lender hability, ${ }^{20}$ the current state of the law is ripe for change. This Note suggests that any changes should strike a balance between a lender's role in protecting its financial interest in a transaction and its role in managing environmental risk through responsible action. This Note adopts an extension of the title/lien theory of lender liability as the appropriate model for determining lender hability, and suggests refinements that address current concerns of both the lending and environmental communities. This Note concludes, however, that Congress is the appropriate branch of government to clarify the law because of the restraints faced by the judiciary and the executive in working within CERCLA's present statutory language. This Note concentrates on various interpretations of the secured creditor exemption, and how this exemption can and should actually be used to protect lenders.

Part I analyzes the currently confused state of CERCLA lender liability. It includes an analysis of the legislative history of both CERCLA as a whole and of the exemption specifically, and an examination of the conflicting interpretations of the actual language of the exeinption as adopted by the different courts faced with the problein. Part II examines the ruling recently proposed by the EPA in light of the judicial interpretations, and analyzes how this ruling proposes to address the problems

17. See Guidice v. BFG Electroplating \& Mfg. Co., 732 F. Supp. 556 (W.D. Pa. 1989); Mary. land Bank, 632 F. Supp. at 573. For a discussion of Guidice, see infra text accompanying notes 13943; for a discussion of Maryland Bank, see infra text accompanying notes 130-38.

18. 15 Envtl. L. Rep. (Envtl. L. Inst.) 20,994 (E.D. Pa. Sept. 4, 1985).

19. Id. at 20,996 .

20. See Phillips, supra note 8 , at 375 . These groups approve of lenders playing an active role in reducing hazards and pricing risky businesses out of the marketplace. Id. These groups also desire to impose affirmative duties on lenders to act as environmental police officers, a position that cannot be supported under the current statutory scheme. See infra note 43. 
that have developed for lenders since CERCLA's inception. Part II includes a section questioning the practical efficacy of the ruling in light of judicial deference doctrine. Part III explores recent legislative proposals that address CERCLA lender liability. Finally, Part IV concludes that carefully considered legislative action can resolve the dilemma of "to lend or not to lend" created by enhanced lender liability under CERCLA, without sacrificing CERCLA's goals.

\section{INTERPRETATIONS OF THE SECURED CREDITOR EXEMPTION}

Of the various defenses and exeinptions within the CERCLA liability scheine, ${ }^{21}$ only two are directly relevant to lender liability issues: the secured creditor exeinption ${ }^{22}$ and the "innocent landowner" defense. ${ }^{23}$ This Note examines the secured creditor exemption, whicl reinoves lenders from the definition of "owner and operator." The exeinption is triggered when a "person," 24 "witliout participating in the manageinent of a vessel or facility, ${ }^{25}$ lolds indicia of ownership primarily to protect his

21. There are three statutory defenses to CERCLA hability that exist when a release of hazardous waste is caused exclusively by an act of God, an act of war, or a third party (subject to very stringent conditions). See CERCLA $\$ 107(b)$, 42 U.S.C. $\$ 9607(b) ;$ Gary L. Klotz \& Ellen C. Siakotos, Lender Liability Under Federal and State Environmental Law: Of Deep Pockets, Debt Defeat and Deadbeats, 92 CoM. L.J. 275, 280-81 (1987). By creating a link to proximate cause, these three defenses provide the only departure from CERCLA's strict liability sclieme. In addition to these three explicit defenses, CERCLA offers exemptions from specific categories and definitions tliat tie imto CERCLA's strict liability scheme. See, e.g., CERCLA § 101(20)(D), 42 U.S.C. $\S 9601(20)(D)$ (exempting state and local government agencies that foreclose on property from the definition of owners and operators).

22. CERCLA $\S 101(20)(A)(i i i), 42$ U.S.C. $\S 9601(20)(A)(i i i)$.

23. Lenders can rely on the innocent landowner defense im the limited setting of foreclosure on real property only if they had no reason to know of a hazardous waste problem, and after the lenders lave made "all appropriate inquiry" into the property to satisfy their duty of "due care." Id. $\S 101(35)(B), 42$ U.S.C. $\S 9601(35)(B) ;$ see also H.R. CoNF. REP. No. 962, 99th Cong., 2d Sess. $187-$ 88 (1986). If a lender "knows" or has "reason to know" of a hazardous waste problem prior to the acquisition of real property, the exemption is inapplicable. See BCW Assoc. v. Occidental Cliem. Corp., No. 86-5947, 1988 U.S. Dist. LEXIS 11275 (E.D. Pa. Sept. 29, 1988) (imposing liability even though defendants carried out environmental audits); Vollmann, supra note 8, at 13 ("For all practical purposes, a lender will always be deemed to lave had reason to know hazardous substances were present because of the rigorous standards constituting the duty to inquire into the previous ownerslip and uses of the property.").

Even if all "appropriate imquiry" is possible, the costs of such imquiry can be prohibitive. See Scott C. Seiler, Comment, The Environmental Due Diligence Defense and Contractual Protection Devices, 49 LA. L. REv. 1405, 1419 (1989). For further developments in the area of the innocent landowner defense, see National Oil and Hazardous Substances Pollution Contingency Plan; Lender Liability Under CERCLA, 56 Fed. Reg. 28,798, 28,806-08 (1991) [hereinafter EPA Proposed Ruling] (to be codified at 40 C.F.R. pt. 300) (proposed by EPA, June 24, 1991).

24. See CERCLA $\S 101(21), 42$ U.S.C. $\S 9601(21)$ (defining “person").

25. See id. $\S 101(9), 42$ U.S.C. $\S 9601(9)$ (defining "facility"). 
security interest in the vessel or facility."26 If the exemption's requirements are met, the person is placed outside the defintion of "owner or operator" and therefore lias an absolute defense to liability imposed by CERCLA upon owners and operators. ${ }^{27}$ Although the existence of this exeinption indicates an intent to offer some level of protection to liolders of security interests (i.e., lenders), the extent of this protection lias been fiercely debated within the three branclies of the federal government and among commentators. The result is a diverse set of interpretations that disagree not only over the degree of protection offered by CERCLA, but also over the pohicy rationales that should be and are applied to support the various interpretations.

This confusion over the intended meaning of the secured creditor exemption arises from three sources: (1) political and economic pressures both for and against applying the exemption; (2) legislative listory that is meager and obscure; and (3) the ambiguity of two key phrases in the exeinption: "participation in the managennent" and "indicia of ownership."28

\section{A. Political and Economic Pressure Influencing Judicial Interpretations of the Secured Creditor Exemption}

Recent judicial interpretations of CERCLA have been inade against a backdrop of significant and soinetimes conflictimg econormic and political pressure. Congress was influenced by political pressure to address the worsening problem of environinental pollution at the inception of the CERCLA legislation. ${ }^{29}$ This pressure has permeated the inost recent

26. Id. $\S 101(20)(\mathrm{A}), 42$ U.S.C. $\S 9601(20)(\mathrm{A})$.

27. Liability is imposed on the present owners and operators of the facility, id. $\S 107(\mathrm{a})(1), 42$ U.S.C. $\$ 9607(a)(1)$, and "any person who at the time of disposal of any hazardous substance owned or operated any facility at which such hazardous substances were disposed of," id. $\S 107(\mathrm{a})(2), 42$ U.S.C. $\S 9607(a)(2)$.

28. These terms, along with "primarily to protect a security interest," have been defined in the EPA Proposed Ruling and in pending legislation that attempts to refine lender liability standards under CERCLA. See infra notes 153-60, 226-27 and accompanying text. Although this Note distinguishes decisions that interpret the secured creditor exemption based on these terms, a distinction can also be drawn based on whether the "facility" is real or personal property. See Klotz \& Siakotos, supra note 21, at 283-89 (categorizing CERCLA lender liability decisions based on whether the lender (1) merely holds a security interest, (2) is a present owner, or (3) is a past owner).

29. CERCLA was originally passed as a response to the environmental threat from indiscriminate releases of industrial hazardous waste, a problem that has been neglected since the birth of the petrochemieal era in the early 1940 s when manufacturers began to use synthetic instead of natural materials. See Virginia L. Martin, Comment, Hidden Hazards of Hazardous Waste Cleanup Laws: Lenders and Title Insurers Beware, 18 CUMB. L. REv. 723, 723-26 (1988).

Two examples illustrate the magnitude of the hazardous waste problem. First, twenty-five miles south of Louisville, Kentucky, a 7-acre site was named the "Valley of the Drums" after more than 17,000 55-gallon drums of chemicals were discovered, almost half of which were oozing waste into the ground. At least $\mathbf{2 0 0}$ organic compounds and $\mathbf{3 0}$ metals were discovered in the water drainage 
congressional and administrative efforts to address the immediate problem of lender liability. Federal agencies have also mcurred significant economic pressure from expanded environmental hability: Because the politically volatile Resolution Trust Corporation (RTC) and Federal Deposit Insurance Corporation (FDIC) not only provide and guarantee loans, but also acquire security interests from failed financial imstitutions, these agencies can inherit the environmental liability associated with the institutions' portfolios, thereby suffering the same fate as private lenders. ${ }^{30}$ Further, the unexpected holding in Fleet Factors has resulted in increased calls for relief from private lenders, businesses, and various other government agencies. ${ }^{31}$ These parties, especially lenders, are becommg increasingly hesitant to enter into transactions that may involve thein in the uncertainties of CERCLA hability. ${ }^{32}$

Uncertainty is a potential factor in tlie current credit- and moneycrunch in environmentally sensitive industries, an indication suggesting to some that such industries should be priced out of the market, ${ }^{33}$ and suggesting to otliers that the current approach to lender liability is smiply inadequate to ensure tlie viability of essential industries while providing protection to the environment. ${ }^{34}$ Congress, altliougli still in the process of reacting to these pressures, has yet to solve the conflict between protecting the environment and protecting lenders from liability in order to

area. S. REP. No. 848, 96th Cong., 2d Sess. 4 (1980), reprinted in 1 SENATE CoMm. ON ENVIRONMENT AND PuBlic WoRks, A Legislative HistoRy of THE COMPREHENSIVE ENVIRONMENTAL Response, Compensation, AND Liability ACT OF 1980 (Superfund), Public LAW 96-510, at 305, 311 (Comm. Print 1983) [hereinafter Legislative History of CERCLA].

Second, Niagara Falls, New York was the victim of the infamous Love Canal disaster, where Hooker Chemical Company had illicitly dumped countless chemical drums in an abandoned canal, paved it over, and sold it to the city for one dollar to provide land for an elementary school and playground. Homes were built nearby, and the population slowly began to suffer the effects of exposure to the poisons: birth defects, miscarriages, epilepsy, liver abnormalities, sores, skin rashes, rectal bleeding, and latent illnesses. See United States v. Hooker Chems. \& Plastics Corp., 680 F. Supp. 546, 549 (W.D.N.Y. 1988); S. REP. No. 848, 96th Cong., 2d Sess., 8-10 (1980), reprinted in 1 LEGISLATIVE HISTORY OF CERCLA, supra, at 315-17.

30. See CERCLA $\$ 120(a)(1), 42$ U.S.C. $\$ 9620(a)(1)$ (applying CERCLA to the federal government "in the same manner and to the same extent . . . as any nongovernmental entity").

31. In addition to the RTC and FDIC, the Small Business Administration (SBA), the Internal Revenue Service (IRS), Farmers Home Administration (FHA), Federal National Mortgage Association ("Fannie Mae"), Federal Home Loan Mortgage Co. ("Freddie Mac"), and the Department of Veterans Affairs can incur hability as secured creditors. See Small Business Hearing, supra note 3 , at 20,33 .

32. See infra note 117 and accompanying text.

33. Campbell, supra note 9, at 8 ("To the extent that [certain industries are priced out of the market] over time, the rate of real economic growth declines, and with it, the rate of growth in real personal income."). Many of these environmentally sensitive industries are America's smaller businesses. See infra notes 263-64 and accompanying text.

34. See supra text accompanying note 3 . 
prevent evisceration of the country's loan-dependent industries. ${ }^{35}$ Until Congress clarifies its policy goals for CERCLA, judicial interpretations will continue to reflect the current conflict.

\section{B. Legislative History and Judicial Interpretation}

The second influence on judicial interpretations of the secured creditor exemption is the legislative history surrounding the passage of CERCLA. This history has not been uniformly interpreted by courts, resulting in the use of broad discretion in construing the exenuption. ${ }^{36}$ Thus, it is not surprising that conflicting judicial interpretations of the exemption's language are nevertheless consistent with at least soine portion of CERCLA's legislative history. Most of these interpretations, however, cannot be convincingly supported on the weight of the statutory language and legislative history alone.

Ouly one interpretation of the exeinption harmonizes the specific language of the exeinption with CERCLA as a whole. ${ }^{37}$ This interpretation of the secured creditor exeenption, adopted by only two district courts, ${ }^{38}$ begins with the premise that Congress's intent for the exeinption was smiply to resolve the inequity of imposing unrestricted ownership hability on a secured lender simply because it held "title" to the property under the law of a state that followed the title-theory of inortgages. ${ }^{39}$ Although this interpretation is the only one consistent with the legislative history as a whole, the courts' various responses to the exeinption's language deinonstrate that there is ample support for alternative approaches. ${ }^{40}$

After establishing the exemption's background in Parts $I(B)(1)$ and (2), Part I(C) traces the various approaches taken by the courts, noting the policies that each approach attempts to further.

35. See infra notes 217-54 and accompanying text.

36. Compare United States v. Mirabile, 15 Envtl. L. Rep. (Envtl. L. Inst.) 20,994, 20,996 (E.D. Pa. Sept. 4, 1985) (lender not liable for merely foreclosing) with United States v. Maryland Bank \& Trust Co., 632 F. Supp. 573, 579-80 (D. Md. 1986) (lender liable as an owner upon foreclosing).

37. But see EPA Proposed Ruling, 56 Fed. Reg. at 28,799 ("The scant legislative listory of the security interest exenıtion slieds little light on this issue.").

38. See Guidice v. BFG Electroplating \& Mfg. Co., 732 F. Supp. 556, 556 (W.D. Pa. 1989); Maryland Bank, 632 F. Supp. at 573; infra notes $130-43$ and accompanying text. These cases liave been overshadowed by two recent circuit court decisions. See In re Bergsoe Metal Corp., 910 F.2d. 668 (9tlı Cir. 1990); United States v. Fleet Factors Corp., 901 F.2d 1550 (11th Cir. 1990), cert. denied, 111 S. Ct. 752 (1991).

39. See infra notes $57-64$ and accompanying text.

40. See infra notes 65-143. 
1. Purposes of CERCLA. Five themes derived from CERCLA's legislative history have provided the cornerstone of the judiciary's analysis of the secured creditor exemption. First, CERCLA has the narrow function of identifying and assuring the cleanup of hazardous waste sites: The introductory language in the Senate Report accompanying CERCLA states that the Act's purpose is "to provide for liability, compensation, cleanup, and emergency response for hazardous substances released into the environment and the cleanup of inactive hazardous waste disposal sites."41 As such, the purpose of CERCLA is to facihtate the cleanup of the environment after a disaster has occurred. CERCLA attempts to hold parties responsible for the cleanup through the over-inclusive $^{42}$ effect of strict liability. Interpretations that rely on the desirability of imposing affirmative duties on parties in general, and on lenders in particular, conflict with this uncoinplicated view of CERCLA. ${ }^{43}$

41. S. REP. No. 848, 96th Cong., 2d Sess. 1 (1980), reprinted in 1 LegisLative History of CERCLA, supra note 29, at 305, 308. To the Eleventh Circuit, this language suggested that "[t]]he essential policy underlying CERCLA is to place the ultimate responsibility for cleaning up hazardous waste on 'those responsible for problems caused by the disposal of chemical poison.' " Fleet Factors, 901 F.2d at 1553 (quoting Florida Power \& Light Co. v. Allis Chalmers Corp., 893 F.2d 1313, 1316 (11th Cir. 1990)); see also Mardan Corp. v. C.G.C. Music, Ltd., 804 F.2d 1454, 1455 (9th Cir. 1986) ("[CERCLA's] purpose was . . to assure that parties responsible for hazardous substances bore the cost of remedying the conditions they created."); United States v. Reilly Tar \& Chem. Corp., 546 F. Supp. 1100, 1112 (D. Minn. 1982) ("Congress intended that those responsible for problems caused by the disposal of chemical poisons bear the costs and responsibility for remedying the harmful conditions they created.").

42. Because of the strict liability scheme, parties not otherwise "responsible" are pulled within CERCLA's grasp. Lenders are often one of these parties.

43. See, e.g., Fleet Factors, $901 \mathrm{~F} .2 \mathrm{~d}$ at $1558 \mathrm{n} .12$ ("The possibility that CERCLA liability will depress the value of the security property provides economic incentive for lenders to guard against its misuse. Lending institutions are especially well-equipped for this function."); see infra note 172 (discussing early EPA draft's imposition of affirmative duties).

Although CERCLA does not impose affirmative duties (with the exception of notice and record-keeping, CERCLA $\S 103,42$ U.S.C. $\$ 9603$ ), other federal or state laws unight do so. If a party falls within a specific liability category provided by another state or federal law, then that statute would determine the party's affirmative duties. RCRA, for example, addresses affirmative duties related to hazardous wastes. See 42 U.S.C. $\S \S 6901-6907,6921-6934$ (1988).

CERCLA and the anended hazardous waste subtitle of RCRA were drafted and discussed at the same time by the same congressional committces. See Frank P. Grad, A Legislative History of the Comprehensive Environmental Response, Compensation and Liability ("Superfund") Act of 1980, 8 COLUM. J. ENVTL. L. 1, 2 (1982). The parallel development of CERCLA and RCRA is a strong indication that the two acts were not intended to conflict, but rather to complement each other. RCRA controls the treatment, storage, and disposal of hazardous wastes. Its comprehensive "cradle to grave" legislation is a proactive, regulatory approach to the hazardous waste management problem. Roberta G. Gordon, Legal Incentives for Reduction, Reuse, and Recycling: A New Approach to Hazardous Waste Management, 95 Y ALE L.J. 810, 811-12 \& 811 n.9 (1986). RCRA establishes standards of behavior and sets up control mechanisms to insure compliance with its standards. CERCLA, on the other hand, regulates the cleanup of existing hazardous substance discharges and provides methods for financing the identification and cleanup of these discharges. CERCLA, in a sense, corrects what RCRA fails to prevent. Yet CERCLA, because of the potentially huge liability 
Second, the legislative history supports a policy that places liability on those " "parties responsible for the creation of hazardous waste sites." "44 The legislative history of S. 1480,45 one of the original bills that contributed to the final version of CERCLA, ${ }^{46}$ states that the purpose was:

[To hold] those who release hazardous substances strictly liable for cleanup costs, mitigation, and third-party damages. Thus, it assures that the costs of chemical poison releases [and any subsequent damage, environmental harm, or injury resulting therefrom] are borne by those responsible for the releases.

...

... [T]he fund [would] be financed largely by those industries and consumers who profit from products and services associated with the hazardous substances which impose risks on society. ${ }^{47}$

This theme has been used to limit CERCLA's reach to those responsible for, or benefitting from, the activities leading to the hazardous waste problem. 48

it imposes, also provides a strong deterrent against improper hazardous waste practices. As a consequence of this deterrent, CERCLA also has a regulatory impact. See Klotz \& Siakotos, supra note 21 , at 294-96.

A conflict occurs between the two acts when CERCLA is read to imply affirmative duties on parties who are not regulated under RCRA's comprehensive scheme. See, e.g., Fleet Factors, 901 F.2d at 1558 (interpreting the exemption in light of lenders' duty to monitor and control borrowers' hazardous waste practices); see infra note 172 . Such schemes add an explicit proactive element, more appropriately exerted from within RCRA's comprehensive regulatory structure than by judicially extending CERCLA's language to include regulatory functions.

44. United States v. Mirabile, 15 Envtl. L. Rep. (Envtl. L. Inst.) 20,994, 20,995 (E.D. Pa. Sept. 4, 1985) (quoting United States v. Northeastern Pharmaceutical \& Chem. Co., 579 F. Supp. 823, 848 (W.D. Mo. 1984), aff'd in part, rev'd in part on other grounds, 810 F.2d 726 (8th Cir. 1986), cert. denied, 484 U.S. 848 (1987)). On signing CERCLA into law on December 11, 1980, President Carter remarked: "[This law] enables the Government to recover from responsible parties the costs of their actions in the disposal of toxic wastes." 16 WEEKLY COMP. PRES. Doc. 2797-2801 (Dec. 15, 1980), reprinted in 1 LEGISLATIVE HISTORY OF CERCLA, supra note 29, at 48-49. Other cases state this policy more generally. See, e.g., Fleet Factors, 901 F.2d at 1553 ("The essential policy underlying CERCLA is to place the ultimate responsibility for cleaning up hazardous waste on 'those responsible for problems caused by the disposal of chemical poison." ") (quoting Florida Power \& Light Co. v. Allis Chalmers Corp., 893 F.2d 1313, 1316 (11th Cir. 1990)).

45. S. 1480, 96th Cong., 2d Sess. (1980), reprinted in 1 Legislative History of CERCLA, supra note 29, at 53-824.

46. See generally Grad, supra note 43, at 1-36 (describing the history of bills leading to the final version of CERCLA).

47. 126 CoNG. REC. 30,932 (1980) (emphasis added) (statement of Senator Jennings Randolph of West Virginia), reprinted in 1 LEgISLATIVE HISTORY OF CERCLA, supra note 29, at 685; see also United States v. Hooker Chems. \& Plastics Corp., 680 F. Supp. 546, 556 (W.D.N.Y. 1988) (CERCLA's purpose was to "[compel] the waste disposal industry to correet its past mistakes and to provide a solution for the dangers posed by inactive, abandoned waste sites"); S. REP. No. 848, 96th Cong., 2d Sess. 13 (1980), reprinted in 1 LEgISLATIVE History OF CERCLA, supra note 29, at 320.

48. See, e.g., Mirabile, 15 Envtl. L. Rep. (Envtl. L. Inst.) at 20,996. 
The third CERCLA theme concerns the fostering of responsible environmental practices and higher standards of care in hazardous substance handhing by providing a financial deterrent to irresponsible practices. ${ }^{49}$ The interplay between the second and third themes-placing the burden on those responsible for the spill and promotimg safer waste practices-is clear: By putting the initial burden to clean up on the owner, operator, disposer, or transporter of the waste, the legislation ${ }^{50}$ "assures that those actually responsible for the incident will undertake the effort to contain the spread of the chemicals and minimize potential damage. This also serves as an incentive for the sound treatinent and handling of hazardous substances in order to prevent accidents im the first place." 51 Courts have used this general proposition to support the imposition of affirmative duties on lenders to momitor their borrowers' affairs, even though the imposition of affirmative duties on lenders is not implied by CERCLA's language or legislative listory. ${ }^{52}$

Fourth, the legislative history provides support for a general rule of construction that resolves ambiguities in CERCLA's language in favor of finding liability. ${ }^{53}$ This theme has been used by courts to broaden CERCLA's reach to unexpectimg potentially responsible parties (PRPs).

49. The legislation is seen as "enforcing higher standards of care by providing for recovery of Government costs of response [to environmentally hazardous sites] . . from liable parties . . .." I LEG1SLATIVE HistoRy OF CERCLA, supra note 29, at 62 (statement of Thomas C. Jorhing, EPA).

50. CERCLA $\S 107($ a), 42 U.S.C. $\S 9607($ a).

51. 125 CONG. REC. 17,989 (1979) (statement of Senator John C. Culver of Iowa), reprinted in 1 LEgisLATIVE HistoRY OF CERCLA, supra note 29, at 148-49.

52. The Fleet Factors court saw the imposition of affirmative duties on lenders as a method of furthering CERCLA's broad goals. See 901 F.2d at 1558; supra note 43 (distinguishing the roles of CERCLA and RCRA in federal environmental strategy).

53. See, e.g., Fleet Factors, 901 F.2d at 1557 ("In order to achieve the "overwhelmingly remedial' goal of the CERCLA statutory scheme, ambiguous statutory terms should be construed to favor liability for the costs incurred by the government in responding to the nazards at such facilities.") (footnote omitted) (citing Florida Power \& Light Co. v. Allis Chalıners Corp., 893 F.2d 1313, 1317 (11th Cir. 1990)). But see Small Business Hearing, supra note 3, at 90-91 (statement of Michael Dore, Esq.) (CERCLA liability originally stood for the principle that " "those who poison the land must pay for its cure" " (quoting State v. Ventron Corp., 468 A.2d 150, 160 (N.J. 1983)), but it "now, to an unfortunate extent, stands for the proposition that any financially viable party which has any association whatsoever with any aspect of a contaminated site, must pay the full reinediation costs for that site.").

The Senate Report accompanying S. 1480 states that to battle the environmental cleanup problein, the legislation provides "a fund to finance a response action where a liable party does not clean up, cannot be found, or cannot pay the costs of cleanup and compensation . . . " S. REP. No. 848, 96th Cong., 2d Sess. 13 (1980) (emphasis added), reprinted in 1 LEgislative HisTORY of CERCLA, supra note 29, at 320. The einphasized portion suggests that the fund (Superfund) is to be used only if a liable party cannot be found, which would tend to increase the vigor of the search for a party who is in any way connected to the offending transaction.

Representative Alex McMillan of North Carolina suggested a further expansion in the search for "deep pockets" to protect the public tax monies already contained in the Superfund: "Why shouldn't we consider a rule that would make attorneys involved in . . . activities [designed to avoid 
The final theme is that the imterpretation of CERCLA may be guided by common law and state and federal statutory law. ${ }^{54}$ Although this approach has been iguored by courts interpreting lender liability under CERCLA, it has been central to the analysis of CERCLA liability of other categories of PRPs. ${ }^{55}$ Courts interpreting the secured creditor exemption have substituted what can be characterized as a federal common law of CERCLA lender hability, redeveloping the law in light of the preceding perceived goals of federal environmental legislation and thereby conflicting with the vital concerns addressed by state common law standards. ${ }^{56}$

2. Purposes of the Secured Creditor Exemption. The secured creditor exeinption originally appeared in H.R. 85, introduced on January 15, 1979.57 An analysis of the original language of H.R. 85, contained in the House Report filed by the Committee on Merchant Marine and Fisheries (to which the bill was referred for cominent) states that:

"Owner" . . d does not include certain persons possessing indicia of ownership (such as a financial institution) who, without participating in the management or operation of a vessel or facility, hold title either in order to secure a loan or in connection with a lease financing arrangement under the appropriate banking laws, rules, or regulations.

CERCLA liability through manipulation of the law] also liable?" Lender Liability Under Superfund: Hearing on H.R. 4494 Before the Subcomm. on Transp. and Hazardous Materials of the House Comm. on Energy and Commerce, 101st Cong., 2d Sess. 54 (1990) [hereinafter Hearing on H.R. 4494].

54. See Grad, supra note 43, at 22-23. CERCLA "contemplates that courts, through common law, would clarify some of the terms of the statute." Hearing on H.R. 4494, supra note 53, at 40 (statement of James M. Strock, EPA). "The Committee [on Interstate and Foreign Commerce] intends that the usual common law principles of causation, including those of proximate causation, should govern the determination of whether a defendant 'caused or contributed' to a release or thrcatened release." H.R. REP. No. 1016, 96th Cong., 2d Sess., pt.1, at 33 (1980), reprinted in 2 LEgiSLATIVE HISTORY OF CERCLA, supra note 29, at 64, and in 1980 U.S.C.C.A.N. 6119, 6136.

55. See, e.g., Edward Hines Lumber Co. v. Vulcan Materials Co., 861 F.2d 155, 157 (7tlı Cir. 1988) (using common law analogies to define operator hability under CERCLA); Julie Mendel, Comment, Interpreting "Owner" and "Operator" Liability Under CERCLA: Edward Hines Lumber Coinpany v. Vulcan Materials Coinpany, 861 F.2d 155 (7th Cir. 1988), 38 WASH. U. J. URB. \& CONTEMP. L. 229 (1990) (observing that Congress in fact intended that common law principles guide CERCLA hability issues).

56. Unlike general statutes that anticipate significant judicial development, for example FED. R. EvID. 501 (privileges), CERCLA consists of speeific statutory provisions.

57. See H.R. 85, 96th Cong., 1st Sess. $§ 101(\mathrm{x})$ (1979), reprinted in 2 Legislative History OF CERCLA, supra note 29, at 480 . The bill's original language read: " '[O]wner' mcans any person holding title to, or, in the absence of title, any other indicia of ownership of, a vessel or facility, but does not include a person who, without participating in the management or operation of a vessel or facility, loolds indicia of ownership primarily to protect his security interest in the vessel or faeility." Id. The original version of CERCLA in the Senate, S. 1480, 96th Cong., 1st Sess. (1979), reprinted in 1 LEGISLATIVE HISTORY OF CERCLA, supra note 29, at 155-92, lacked an exemption from the definition of "owner or operator" for secured creditors. 
... For example, a financial institution which held title primarily to secure a loan but also received tax benefits as the result of holding title would not be an "owner" as long as it did not participate in the management or operation of the vessel or facility. ${ }^{58}$

The Committee thus expressly recognized that holding title merely as a consequence of securing or in connection with a security interest is often inevitable, and that these consequences should not automatically create hability for the lender.

Before H.R. 85 was passed by the House, Representative William $H$. Harsha of Ohio introduced an amendment ${ }^{59}$ to H.R. 85 on the House floor with accompanying reinarks:

This change was necessary because the original definition inadvertently subjected those who hold title to a vessel or facility, but do not participate in the management or operation and are not otherwise affiliated with the person leasing or operating the vessel or facility, to the liability provisions of the bill.

... [T] hose that hold title cannot be affilated [sic] $\mathrm{m}$ any way with those who lease or charter the vessel or facility..$^{60}$

Representative Harsha's "affiliated" language was used by the Eleventh Circuit in Fleet Factors to support a narrow construction of the secured creditor exemption. ${ }^{61}$ The court reasoned that even "peripheral" involvement by a lender in a facility's affairs, as opposed to "the management of day-to-day operations standard set forth in Mirabile," is sufficient to reinove the exemption's protection. ${ }^{62}$ When Representative

58. H.R. REP. No. 172, 96th Cong., lst Sess., pt.1, at 36 (1979) (emphasis added), reprinted in 2 LEGISLATIVE HISTORY OF CERCLA, supra note 29, at 525, 546, and in 1980 U.S.C.C.A.N. 6160 , 6181.

59. The amended language read:

"[O]wner" means any person holding title to, or, in the absence of title, any other indicia of ownership of, a vessel or facility, but does not include a person who (either directly or through a trust or singly or in combination with others) holds title to or any indicia of ownership of a vessel or facility and without participating in the managenent or operation of such vessel or facility, leases or charters to any other person (with whom such person is not otherwise affiliated), or holds indicia of ownership primarily to protect his security interest in the vessel or facility ....

H.R. 85, 96th Cong., 2d Sess. $\S 101(x)$ (1980) (emphasis added) (statement of Rep. Harsha), reprinted in 2 LEGISLATIVE HISTORY OF CERCLA, supra note 29, at 1021-22. Although Representative Harsha's language did not appear in the final version of CERCLA, the history behind the evolution is useful in understanding the exemption. See supra text accompanying notes 24-26 (quoting CERCLA's adopted language).

60. 126 CONG. REC. 26,212 (1980) (emphasis added), reprinted in 2 LEGISLATIVE HistoRY of CERCLA, supra note 29, at 945; see also H.R. REP. No. 172, 96th Cong., 2d Sess., pt. 2, at 3 (1980) (report of Committee on Public Works and Transportation concurring with the "affiliated" language), reprinted in 2 LEGISLATIVE HISTORY OF CERCLA, supra note 29, at 615, and in 1980 U.S.C.C.A.N. 6212, 6213-14.

61. See United States v. Fleet Factors Corp., 901 F.2d 1550, 1558 n.11 (11th Cir. 1990), cert. denied, $111 \mathrm{~S}$. Ct. 752 (1991).

62. Id. This conclusion has been criticized by some commentators, one of whom stated that "[i]t seems more likely that the phrase ['otherwise affiliated'] is really a few 'throw away' words by a 
Harsha made his comments, however, he was not discussing the degree of involvement of a lender in the affairs of its borrower. Rather, he used the word "affiliated" to refer to sham 'corporations. His changes were intended 'to prevent the establishment of 'dummy' corporations, with few assets, which would be the responsible party for the purpose of the act." 63 Representative Harsha's language demonstrates a desire to clarify the original language by providing that polluters would not be able to envelop themselves in a sham corporate entity and thereby avoid hability. ${ }^{64}$ To Representative Harsha, the exemption was intended to protect lenders ouly when they are acting as lenders, and not when they are using their status as lenders to protect themselves from liability, when in fact their involveinent with the firm extends beyond a debtor-creditor relationship.

\section{The Ambiguous Language of the Secured Creditor Exemption: Judicial Interpretations}

The two critical phrases of the secured creditor exemption, "without participating in the managennent" and "holds indicia of ownerslip pri1narily to protect his security interest," 65 have provided ineans by which the courts have created confusion as to the exemption's intended meaning. Parts $I(C)(1)$ and $I(C)(2)$ discuss judicial decisions interpreting each of the exemption's clauses in light of the above discussion of the different aspects of the legislative history.

congressman who did not expect to be cited for statutory construction. Such an obscure expression provides flimsy support for turning an exemption ... into a hability ...." Robert B. Koegel, Bank Power Draws Superfund Liability, N.Y. L.J., July 9, 1990, at 1, 5. Although correct in criticizing the court for its interpretation, the analysis accompanying this critieisin is flawed. When Representative Harsha's commentary to his amendinent is examined in context and in light of his introductory reinarks, it seems reasonable that he would choose his words carefully: "Mr. Chairman, I would like to discuss [the provision defining "owner"] for the purpose of establishing legislative history." 126 CONG. REC. 26,212 (1980) (emphasis added), reprinted in 2 LEGISLATIVE HisTORY OF CERCLA, supra note 29 , at 944 .

63. 126 CONG. REC. 26,212 (1980), reprinted in 2 LEgISLATIVE HISTORY OF CERCLA, supra note 29, at 945. The term "affiliated" was specifically defined in the final version of H.R. 85, though it was not included in CERCLA: " '[A]ffiliated' ineans a relationship in which a person owns (in whole or in part), is owned by (in whole or in part), or is under coininon control with, another person." H.R. 85, 96th Cong., 2d Sess. $\S 101(y)$ (1980), reprinted in 2 LEGISLATIVE HiSTORY OF CERCLA, supra note 29, at 1022. This definition does not support the reading given to the term "affiliated" by the court in Fleet Factors. 910 F.2d at 1558 n.11.

64. See Sean P. Madden, Note, Will the CERCLA Be Unbroken? Repairing the Damage After Fleet Factors, 1990 FordHAM L. REv. 135, 153-54 \& nn.125-31.

65. 42 U.S.C. $\S 9601(20)(A)$. 
1. Participation and Lenders' Intent to Protect Security Interests. Courts have adopted two approaches in defining the types of participation that reinove a secured creditor from the exeinption's protection. Under the first approach, participation occurs only through active involveinent by a lender in the day-to-day operations of a facility. ${ }^{66}$ Under the second approach, participation occurs when a lender inerely has the capacity to influence a facility's hazardous waste practices. ${ }^{67}$ This latter approach permits the imposition of hability without any affirmative action by the lender.

This stark difference in approaches is heightened by the interjection of an intent-based analysis. Some courts have held that when a lender participates with an intent to protect its security interest, such participation does not relnove the exemption's protection. ${ }^{68} \mathrm{~A}$ plain-language construction of the exemption unambiguously rejects this intent-based approach for examining "participating in the management."69 Courts adopting an intent-based analysis, however, have looked beyond the exemption's language, relying instead on stramed interpretations of CERCLA's legislative history ${ }^{70}$ to reach what appear to the courts to be necessary results. The effect has been to dismiss the exemption's language in order to permit limited participation, including foreclosure and actions to maintain the facility after foreclosure, ${ }^{71}$ which is necessary to protect a lender's security interest.

In contrast to the intent-based approach, under the narrow title/lien theory imterpretation of the exemption, 72 "participating in the manageinent" is used as a threshold test to determine whether the lender is, im 1985).

66. See United States v. Mirabile, 15 Envtl. L. Rep (Envtl. L. Inst.) 20,994 (E.D. Pa. Sept. 4,

67. See United States v. Fleet Factors Corp., 901 F.2d 1550 (11th Cir. 1990), cert. denied, 111 S. Ct. 752 (1991).

68. See, e.g., In re T.P. Long Chem., Inc., 45 B.R. 278, 288-89 (N.D. Ohio 1985); infra notes 125-29 and accompanying text. Fleet Factors rejects intent as a factor in the determination of permissible participation. Fleet Factors, 901 F.2d at 1560.

69. Within the exemption's language, see supra text accompanying notes $24-26$, the "without participating in the management" prepositional phrase refers to the actions of the person who is potentially exempted. Only the verb "holds" is modified by the phrase "primarily to protect his security interest." The verb clause incorporates the intent element; thus, on its face, the exemption's language does not support an expansive standard of "participation" that would include participation intended to protect a secured interest. Indeed, Fleet Factors recognized this fact:

[The] assertion [of intent], even if true, is immaterial to our analysis. The scope of the secured creditor exemption is not determined by whether the creditor's activity was taken to protect its security interest. What is relevant is the nature and extent of the creditor's involvement with the facility, not its motive.

901 F.2d at 1560 .

70. See supra text accompanying notes 41-64.

71. See, e.g., Mirabile, 15 Envtl. L. Rep. (Envtl. L. Inst.) at 20,996.

72. See supra text aecompanying notes $57-64$. 
fact, a holder of a security interest. Liability results only when the lender becoines a true owner (i.e., through foreclosure) or if the lender participates in management to a degree imdicating "operator" status. ${ }^{73}$ The two judicial approaches to "participating in the management" could have been used to perform this threshold analysis. ${ }^{74}$ Yet the question posed by the courts has consistently been whether the lender can qualify for protection under the secured creditor exemption, rather than whether the defendant is in fact a "lender."

a. Day-to-day operations standard of participation. Two decisions, United States v. Mirabile ${ }^{75}$ and In re Bergsoe Metal Corp. ${ }^{76}$ distinguish between participation in the financial management of a facility, which they found to be permissible under the exemption, and participation in the day-to-day operations and management of a facility, which they found removes the exemption's protection.

Mirabile involved three defendants: American Bank and Trust Company (ABT), Mellon Bank, ${ }^{77}$ and the Small Busmess Administration (SBA). Each defendant was involved in financing the operations of Turco Coatings, Inc., a paint manufacturer, and each held security interests in portions of Turco's property to protect their financial interests.78 The Mirabile court's treatment of the three defendants provides a unique "study in contrasts" of the degree of acceptable participation" study apphicable to ouly one approach to interpreting the exemption.

The first lender, ABT, had "merely foreclosed on the property after all operations had ceased and thereafter took prudent and routine steps

73. See Joslyn Mfg. Co. v. T.L. James \& Co., 893 F.2d 80 (5th Cir. 1990), cert. denied, 111 S. Ct. 1017 (1991); Edward Hines Lumber Co. v. Vulcan Materials Co., 861 F.2d 155 (7th Cir. 1988).

74. See supra text accompanying note 66-67.

75. 15 Envtl. L. Rep. (Envtl. L. Inst.) 20,994 (E.D. Pa. Sept. 4, 1985). For other analyses of Mirabile, see Susan C. Gieser, Federal and State Environmental Law: A Trap for the Unwary Lender, 1988 B.Y.U. L. REV. 643, 662-667, 672-78; Klotz \& Siakotos, supra note 21, at 306-09; Scott Wilsdon, Note, When a Security Becomes a Liability: Claims Against Lenders in Hazardous Waste Cleanup, 38 HAsTINGs L.J. 1261, 1275-80 (1987).

76. 910 F.2d 668 (9th Cir. 1990).

77. Liability alleged against Mellon was based on involvement by Mellon's predecessor-in-interest. Mirabile, 15 Envtl. L. Rep. (Envtl. L. Inst.) at 20,997.

78. Id. At the time of the case, Thomas and Anna Mirabile were the owners of the property on which the Turco facility was located. They acquired ownership of the property following a foreclosure sale due to Turco's bankruptcy. Id. at 20,996. The Mirabiles took title to the property pursuant to an assignment by ABT of its bid in the foreelosure proceeding. Id. Upon discovery that the site was contaminated, the EPA filed an action for the costs of the cleanup against the Mirabiles. Id. at 20,995 . The Mirabiles, in turn, joined both banks as third party defendants, claining they were liable for hazardous conditions at the Turco site that were created during the bank's financial dealings with Turco. The banks proceeded to file counterclaims against the United States "relying on the alleged involvement of the [SBA] in creating the conditions existing at the site." Id.

79. See Mays, supra note 8 , at 610 . 
to secure the property against further depreciation." 80 The court found that ABT was not liable because it did not participate in the "day-to-day operational aspects of the site." 81 Noting that the exeinption did not mention participating in the managennent of the financial affairs of the owner or operator of a facility, the court concluded that "Congress intended to draw a distinction between parties involved in the actual operation of the facility and those who are involved in what may properly be characterized as the financial aspects of the business conducted at the facility." 82 Thus, "Inere financial ability to control waste disposal practices of the sort possessed by the secured creditors in this case [was] not ... sufficient for the imposition of hability." 83

The court also ruled in favor of the SBA on its motion for summary judgment. The court noted that although the SBA loan agreement required Turco to obtain SBA approval prior to the execution of certain contracts and contained a number of restrictions on the financial activities of Turco, ${ }^{84}$ the SBA never provided management assistance to Turco (although required by its regulation to do so) and did not take title to the site. ${ }^{85}$ The court, in finding that the SBA was protected by the exemption, reemphasized that "participation in purely financial aspects of operation ... is [not] sufficient to bring a lender within the scope of CERCLA liability." 86

80. Mirabile, 15 Envtl. L. Rep. (Envtl. L. Inst.) at 20,996. The court stated that the activities undertaken "by ABT with respect to the site simply cannot be deemed to constitute participation in the management of the site." Id. The EPA Proposed Ruling would support this conclusion. See infra text accompanying notes 161-92. ABT had foreclosed on its inortgage, secured the buildmg against vandalisin by boarding up windows and changing locks, visited the property on a number of occasions to show it to prospective customers, mquired as to the cost of disposal of drums containing hazardous substances on the site, and purchased the property at the foreclosure sale and assigned it to the Mirabiles. 15 Envtl. L. Rep. (Envtl. L. Inst.) at 20,996.

81. Mirabile, 15 Envtl. L. Rep. (Envtl. L. Inst.) at 20,996. The court did not base its ruling on the change in ABT's title caused by the foreclosure proceedings; ABT's "actions with respect to the foreclosure were plaiuly undertaken in an effort to protect its security interest in the property." Id.

82. Id. at 20,995-96 (emphasis added) (citing H.R. KEP. No. 172, 96th Cong,, 2d Sess., pt.1, at 36-37 (1979) (defining "operator" as a person carrying out operational functions for the owner of the facility), reprinted in 2 LEGISLATIVE HISTORY OF CERCLA, supra note 29, at 546-47); see also id. at 20,995 (stating that usage of "facility" suggests critical participation is in the "operational, production, or waste disposal activities").

83. Id. at 20,995 .

84. The SBA loan agreement restricted the compensation of Turco officers and the paynents of dividends to Turco shareholders, and required that the written consent of SBA be obtained prior to the purchase of life insurance or the paymeut of advances to Turco officers and the execution of any contracts for management consulting services. Id. at 20,996.

85. Id. at 20,997 . The lack of title suggests that the Mirabiles' claim might have been more appropriately characterized as involving "operator" liability. SBA representatives did visit the site three times to monitor the liquidation of assets. Id. at 20,996 .

86. Id. at 20,997 . 
Although ABT and the SBA both fell within the exemption's protection, the court ruled that Mellon's alleged participation in Turco's day-to-day operations was sufficient, if substantiated, to incur liability. Thus, Mellon's motion for summary judgement was denied. ${ }^{87}$ The court found that the participation by one Mellon loan officer, who merely "gave general financial advice and did not discuss production or waste disposal," was permissible under the exemption. ${ }^{88}$ A second loan officer's actions, however, indicated involvement in Turco's day-to-day operations, and thus subjected the bank to potential liability. ${ }^{89}$

There are three important implications of the Mirabile court's approach: Actual involvement in the operations of the facility is necessary to constitute participation; participation in the management of a facility does not necessarily need to affect hazardous waste practices; and intent is not the determinative factor because participation that is intended solely to protect a security interest can nevertheless destroy the exemption's protection. The Mirabile court permitted a lender to take active control of a facility through foreclosure without losing the exemption's protection, because it found that a lender's right to foreclose was itself protected. ${ }^{90}$ This form of active participation simply constituted a necessary step in the exercise of a lender's protection of its security interest.

In re Bergsoe Metal Corp. 91 involved a local port authority, the Port of St. Helens, which held certain properties as security for financing a lead recycling plant.92 In finding that the Port was not liable under CERCLA, the Ninth Circuit estabhished a test of permissible involvement under the exemption paralleling Mirabile's day-to-day involveinent standard. The court stated that "[i]t is clear from the statute that, whatever the precise paranieters of 'participation,' there must be some

87. Id. Howcver, the court remarked that "[t]he reed upon which the Mirabiles seek to impose liability on Mellon is slender indeed ...." Id.

88. Id.

89. In addition to monitoring the financial condition of the company (an activity insufficient, by itself, to give rise to liability, see id.) the Mcllon loan officer liad visited the site on a weekly basis and had allegedly insisted on additional sales efforts, manufacturing changes, and reassignments of personnel. Id. There was no indication, however, that the loan officer affected the handling of the facility's hazardous waste.

90. See id. at 20,996 .

91. 910 F.2d 668 (9th Cir. 1990).

92. The Port, a municipal corporation empowered to issue revenue bonds to promote industrial development, entered into an agreement with Bergsoe Metal Corporation for which the Port pro. vided land and issued bonds to finance the development of Bergsoe's facility. Id. at 669 . The bonds were held by a bank in trust for the bondholders, to provide funds for the acquisition of land and the construction of a recycling plant. The revenue from bond sales went to Bergsoe, which was obligated to pay the money owed on the bonds to the Port, which then transferred the funds to the bank. The Port had not actively participated in Bergsoe's inanagement but did have the contractual right to do so. Id. at 672-73. 
actual management of the facility before a secured creditor will fall outside the exception."93

The Ninth Circuit also held that CERCLA does not impose an affirmative duty upon lenders to control borrowers' hazardous waste practices. ${ }^{94}$ The Ninth Circuit, consistent with an earher bankruptcy case, In re T.P. Long Chemical, Inc. , ${ }^{95}$ emphasized what it perceived as financial reality:

Creditors do not give their money blindly, particularly the large sums of money needed to build industrial facilities. Lenders normally extend credit only after gathering a great deal of information about the proposed project, and only when they have some degrec of confidence that the project will be successful. A secured creditor will always have some mput at the planning stages of any large-seale project and, by the extension of financing, will perforce encourage those projects it feels will be successful. 96

This pragmatic approach provides support for the traditional role of security holders in inaintaining soine involvement in their borrowers' activities. ${ }^{97}$ If such involvelnent removed the protection of the exemption, the court observed, then "no secured creditor would ever be protected."98

93. Id. at 672 (emphasis added). Although specifically stating it would not address the problems created by dicta in Fleet Factors, the Ninth Circuit's reasoning logically rejects the "capacity to infuence" standard. See infra note 101-05 and accompanying text. The Bergsoe court did address the questions raised by Fleet Factors, but read the case as requiring some form of actual management and not merely "the power to manage," an interpretation possible only if the Eleventh Circuit's dicta is ignored. See Bergsoe, 910 F.2d at 673 n.3 ("Merely having the power to get involved in management, but failing to exercise it, is not enough."); see also M. Joel Bolstein \& Lois Reznick, Lender Liability After Fleet Factors, ENVTL. L., Fall 1990, at 1, 3.

94. See Bergsoe, 910 F.2d at 673 n.3.

95. 45 B.R. 278 (N.D. Ohio 1985). T.P. Long was the first reported decision to analyze the secured creditor exemption. The bankruptcy court, in reviewing an EPA atteinpt to subordmate BancOhio National Bank's seeurity interest in portions of the debtor's estate, suggested an intentbased standard under which participation by lenders aimed at protecting a security interest does not constitute sufficient participation to remove the exemption's protection. See id. at 289. For other analyses of T.P. Long, see Klotz \& Siakotos, supra note 21, at 311-12; Patricia L. Quentel, The Liability of Financial Institutions for Hazardous Waste Cleanup Costs Under CERCLA, 1988 WIs. L. REV. 139, 161-64.

96. Bergsoe, 910 F.2d at 672 . Mirabile also refused to be tempted by the potential benefits of broadly defined liability:

Obviously, imposition of habihty on seeured creditors or lending institutions would enhance the government's chances of recovering its cleanup costs, given the fact that owners and operators of hazardous waste dumpsites are often elusive, defunct, or otherwise judgment proof. It may well be that the imposition of such liability would help to ensure more responsible management of such sites. The consideration of such policy matters, and the decision as to the imposition of such hability, however, lies witl Congress. In enacting CERCLA Congress singled out seeured creditors for protection froin liability under certain circumstances.

United States v. Mirabile, 15 Envtl. L. Rep. (Envtl. L. Inst.) 20,994, 20,996 (E.D. Pa. Sept. 4, 1985).

97. The EPA Proposed Ruling explicitly adopts this approacl. See infra notes 155-56 and accompanying text.

98. Bergsoe, 910 F.2d at 672 (footnote omitted). 
To support its position, the court stated: "The CERCLA security interest exemption uses the active 'participatimg in inanagement.' Regardless of what rights the Port may have had, it cannot have participated in 1nanagement if it never exercised thein." 99 Thus, "[w]hat is critical is not what rights the Port had, but what it did." 100

\section{b. Capacity to influence: The Fleet Factors standard of partic-} ipation. In United States v. Fleet Factors Corp. ${ }^{101}$ the Court of Appeals for the Eleventh Circuit based its interpretation of the secured creditor exeinption on what a lender could do-that is, its ability to minimize or prevent environmental problems through participation. ${ }^{102}$ The Eleventh Circuit ${ }^{103}$ departed from all lower court interpretations of "participating in the inanagement" and created a new standard:

[A] secured creditor may incur ... liability, without being an operator, by participating in the financial inanageinent of a facility to a degree indicating a capacity to influence the corporation's treatınent of hazardous wastes. ... [A] secured creditor will be liable if its involveinent with the inanagenent of the facility is sufficiently broad to support the

99. Id. at $672-73$ (footnote omitted).

100. Id. at 672 .

101. 901 F.2d 1550 (11th Cir. 1990), cert. denied, 111 S. Ct. 752 (1991). Fleet Factors Corp. and Swainsboro Print Works, Inc. (SPW), a cloth printing facility, entered into an agreement in which Fleet agreed to advance funds to SPW against the assignment of accounts receivable and a security interest in SPW's facility, including equipment, inventory, and fixtures. Id. at 1552. After SPW entered bankruptcy proceedings, the agreement was pernitted to continue, allowing Fleet to collect on the accounts receivable until Fleet foreclosed on a portion of its security interest in SPW's inventory and equipinent. Id. Fleet arranged for an auction of the collateral and for the removal of the unsold equipment. Id. at 1553 .

The EPA inspected the facility in January of 1984 . Over 750 gallon drums of toxic chemicals and 44 truckloads of material containing asbestos were discovered at the site, apparently the remains of SPW's industrial operation. Id. Asbestos had also been released during the sale and removal of the facility's equipment, which had been arranged by Fleet. Id. at 1560 n.14. The government filed suit against Fleet for reimbursement of costs incurred in the cleanup of the site. Id. at 1553.

102. In an early footnote, the court disposed of the issue of CERCLA liability by finding that Fleet was an "operator" under section 107(a)(1). See id. at 1556 n.6. However, because the court felt that the case fit "more snugly" under a secured creditor analysis, an analysis of Fleet's liability as an operator was omitted. Id. Because the court already had a hook on which to hang Fleet, the majority, if not all, of the controversial positions in the opinion are dicta.

103. Oral arguments were heard by Judges Robert $S$. Vance and Phyllis A. Kravitch of the Eleventh Circuit and Judge Seybourn H. Lynne, a Senior U.S. District Judge, Northern District of Alabama, sitting by designation. Id. at 1552. Judge Vance, who died on December 16, 1989, did not participate in the decision. See Madden, supra note 64, at 146 n.80; James P. O'Brien, The 'Fleet Factors' Decision: Its Effect on Secured Lending, 5 Toxics L. REP. (BNA) 23, 25 n.1 (1990) (suggesting that these circumstances could affect the decision's value as precedent). 
inference ${ }^{104}$ that it could affect hazardous waste disposal decisions if it so chose. ${ }^{105}$

At the heart of the Eleventh Circuit's analysis is the general pohicy of resolving ambiguities in CERCLA in favor of finding liability. ${ }^{106}$ The court used this basic policy to derive two straiglitforward concepts: (1) A lender who fails to prevent a hazardous waste problein lias participated in the creation of that environmental problem; ${ }^{107}$ and (2) the government should not be an insurer of a lender's security wlien the value of the security is depleted by liazardous waste releases. ${ }^{108}$ But although tliese concepts have soine logical appeal, the authority and reasoning

104. The court stated that such an inference in this case:

is not even necessary because there was evidence before the district court that Fleet actively asserted its control over the disposal of hazardous wastes at the site by prohibiting SPW from selling several barrels of chemicals to potential buyers. As a result, the barrels remained at the facility unattended until the EPA acted to remove the contaminants.

Fleet Factors, 901 F.2d at 1559 n.13. Because of this fact, the "inference" language also appears to be dicta. See supra note 102.

105. Id. at 1557-58 (emphasis added) (footnotes omitted). In adopting this standard of liability, the court explicitly rejected the "day-to-day operation" formulation of the exemption adopted by Mirabile and other cases. See, e.g., United States v. Northeastern Pharmaceutical \& Chem. Co., 810 F.2d 726, 743-44 (8th Cir. 1986) (stating that CERCLA can impose liability on persons who have the authority to implement abatement measures), cert, denied, 484 U.S. 848 (1987); United States v. Consolidated Rail Corp., 729 F. Supp. 1461, 1468 (D. Del. 1990) ("[T]hose who "actually operate or exercise control over the facility that creates an environmental risk can be held hable under CERCLA for the costs of reducing that risk." (quoting Edward Hines Lumber Co. v. Vulcan Materials Co., 685 F. Supp. 651, 657 (N.D. Ill.), aff'd, 861 F.2d 155 (7th Cir. 1988))). Although the court's holding is generally considered a surprise, at least one commentator did recognize the possibility that having the right to manage or control could create liability. See Martin R. Ufford, Avoiding the Spectre of Environmental Liability: Recommendations for Financial Institutions and Trust Companies, J. KAN. BAR Assoc., Jan. 1990, at 15, 19.

106. See supra text accompanying note 53.

107. Cf. Christopher H. Schroeder, Two Methods for Evaluating Duty to Rescue Proposals, LAw \& CONTEMP. PROBS., Summer 1985, at 181 (acknowledging the similarity between failures to act and failures to rescue and arguing against the "American view" that there is no duty to rescue). This concept of responsibility is similar to criminal law bystander liability and tort and contract law omission standards. The source of the law, however, is very different. The criminal, tort, and contract law doctrines typically arose from common law notions of equity and social responsibility. See generally Wayne R. LAFAVE \& Austin W. ScotT, JR., Criminal LAW § 3.3 (2d ed. 1986). The Fleet Factors court, on the other hand, relied on statutory interpretation. In so doing, it read the exemption's language together with carefully selected portions of the legislative history to arrive at an expansive definition of "participation," a definition broad enough to include omissions. Such an interpretation is directly at odds with the title/lien theory interpretation. Further, as the Bergsoe court points out, the exemption uses the active form of the verb participating. See In re Bergsoe Metal Corp., 910 F.2d 668, 672-73 (9th Cir. 1990). This suggests that omissions were not intended to constitute participation under the exemption.

The Eleventh Circuit's basic point, however, is sound. The danger caused by hazardous waste seems sufficient to impose liability on any persons who are in a position to minimize this danger.

108. This second concept is a corollary to a fundamental principle embodied in CERCLA's structure and legislative history: Persons involved with the facility are responsible for the cleanup and should therefore be forced to incur the cleanup costs. See supra text accompanying note 44. 
used by the court in applying thein is questionable. ${ }^{109}$ Most conspicuous is the court's assumption that if a lender falls outside of the exemption, then imposition of hability is appropriate. This approach essentially "turns [CERCLA] on its head by using the exemption to subject lenders to hability rather than to shield lenders from hability."110

Not surprisingly, the Eleventh Circuit's interpretation of the exemption has received substantial criticism motivated both by the implications of the rule and the court's approach to statutory construction. ${ }^{111}$ The impetus for much of this criticisin is that by establishing such a narrow interpretation of the exemption the decision inay force lenders to avoid risky industries. In its opimion, the court recognized and then summarily dismissed this conceru: "While there is a clear risk that innocent borrowers will find it difficult to obtain credit because of the nature of their business, this result is consistent with CERCLA's general effect of spreading hazardous waste costs industry-wide."112 The court felt that because lenders are present at most facilities, the availability of CERCLA's huge deterrent effect through a narrow interpretation would give a lender incentive to inomitor, and when necessary control, the hazardous waste practices of its borrower. ${ }^{113}$ Yet, the court ignored the fact

109. See supra text accompanying notes 61-64.

110. Petition for Certiorari of Fleet Factors Corp. at 8, Fleet Factors Corp. v. United States, 111 S. Ct. 752 (No. 90-504). For a recent example of a court adopting this interpretation, see Resolution Trust Corp. v. Polmar Realty, Inc., 780 F. Supp. 177, 180 (S.D.N.Y. 1991) ("[S]ecured lenders may be liable for environmental cleanups under CERCLA even prior to taking title if they have exercised a certain degrce of control over the property." (citing United States v. Fleet Factors Corp., 901 F.2d 1550 (11th Cir. 1990), cert. denied, 111 S. Ct. 752 (1991))). In reaching this conclusion, the Polmar court apparently misread Fleet Factors' language. Id. ("[A] secured creditor will be liable if its involvement with the management of the facility is sufficiently broad to support the inference that it could affect hazardous waste disposal decisions if it so close." (quoting Fleet Factors, 901 F.2d at 1558)). See Petition for Certiorari of Flect Factors Corp. at 8, Fleet Factors (No. 90-504); Fleet Factors, 901 F.2d at 1556 n.6 ("Flect can be held hable if it had an indicia of ownership to remove it from the secured creditor liability exemption.") (citation omitted); see Madden, supra note 64, at $154-55 \& 155 \mathrm{n} .133$. There is a resolution of this ambiguity in the Fleet Factors language: The court might have meant that secured creditors who loold indicia of ownership are liable as owners unless they are able to inect the secured creditor exemption's test. Contra id. at $147 \mathrm{n} .82$ ("While subtle, the court's syntax unmasks its approach [as to] whether participation in management was sufficient to impose liability. . . . The court extended syntactical error to its logical extreme by using the exception to carve out a new class of [PRPs] under CERCLA.").

111. See, e.g., Madden, supra note 64, at 148 ("The reaction to Fleet Factors was swift and overwhelmingly negative."); id. at $148 \mathrm{n.93}$ (citing additional authority).

112. 901 F.2d at 1559 n.12 (quoting Wilsdon, supra note 75 , at 1295).

113. This analysis presumes, however, that lenders have the skill to perform this monitoring function, that they will be able to shift the cost of their new liability to borrowers, and that they are able to evaluate this new form of risk. For an article advocating this position, see Roslyn Tom, Note, Interpreting the Meaning of Lender Management Participation Under Section 101(20)(A) of CERCLA, 98 YALE L.J. 925, 931-33 (1989) (encouraging courts to impose duties to monitor on lenders). For a discussion of the effeet of uncertainty on risk premiums, see infra text accompanying note 117 . 
that this capacity to influence test would "in virtually all instances be satisfied, if not by the rights and powers afforded to lenders under typical commercial loan agreements, then surely by the conduct of lenders that the [court's] opinion expressly encourages." 114

The Eleventh Circuit's "capacity to influence" standard could have a sweeping impact on all secured transactions within the lending community. ${ }^{115}$ Under the Fleet Factors decision, lenders are insurers of the environmental damage caused by their borrowers regardless of the amount of the loan or the perception of hability at the time the loan was established. ${ }^{116}$

In addition to busimess and environmental risks, lenders nust also conipensate for the risk created by the uncertain scope of the court's ruling. ${ }^{117}$ The decision did not address, for example, what "financial dealings" can establish "a capacity to influence." This situation is

114. Petition for Certiorari of Fleet Factors Corp. at 9, Fleet Factors (No. 90-504). For examples of actions that the court considered appropriate for a lender to undertake, see Fleet Factors, 901 F.2d at 1558 n.12. These actions would be within the EPA Proposed Ruling's interpretation of the exemption's protection. Unsuccessful legislation also attenpted to create such protection. See infra text accompanying notes 217-54.

115. See, e.g., infra note 218 and accoinpanying text. Fleet Factors Corporation, in its petition for certiorari, provided a laundry list of claimed potential effects:

[T] he already wary banking industry [will be] even inore reluctant to lend to many borrowers, not just those who present obvious environmental hability problems, and less willing to help troubled borrowers through difficult financial times. Inhibited financial transactions and modified lending practices will reduce the supply and increase the cost of capital for many borrowers. Old industrial property is likely to remain abandoned and unused for fear of environmental liability. Increased caution on lenders' part will probably result in more bankruptcies, since helping a borrower overcome financial dificulties will seldoun be worth the risk of cleanup liability, considering the unpredictable scope of CERCLA damages. In fact, if courts attempt to follow the lolding of the Eleventh Circuit, lenders will be liable in countless unpredictable situations.

Petition for Certiorari of Fleet Factors Corp. at 6, Fleet Factors (No. 90-504).

116. See Fleet Factors, 901 F.2d at 1557-59. The court addressed this potential inpact, but only as to future transactions. See id. at 1558; infra text accompanying notes 276-77. The court suggested that lenders could coinpensate for potential cnvironmental liability by charging higher interest rates. See id.

117. Although uncertainty of the current law forces lenders to make financial decisions without sufficient infornation to assess and reduce environmental risk, the existence of such uncertainty potentially serves two purposes within a statutory scheme. First, uncertainty tends to compel parties to apply broader interpretations of CERCLA when considering liability issues. See RICHARD A. POSNER, ECONOMIC ANALYSIS OF LAW 514 (3d ed. 1986). Second, uncertainty in the statutory scheme discourages the discovery and use of legal loop looles, see id., because courts will rejeet any argument that is perceived to threaten the purposes of CERCLA.

On its surface, this policy appears to be environmentally sound: By assuming the worst, lenders must do everything possible to avoid both liability and harm to the environinent. Yet, this assunnes that lenders should do everything possible. Some actions that limit liability, such as refusal to infiuence hazardous waste disposal decisions even when a problem is apparent, nay actually increase the risk of damage to the environinent and, therefore, decrease the value of the lender's collateral. Moreover, other parties inay be better equipped to police the environinent. Additionally, this policy leads to an inefficient use of existing resources: It encourages inanufacturers to build new plants 
complicated by the court's contradictory statement that "[s]ecured lenders [can] frequently have some imvolvement in the financial affairs of their debtors in order to insure that their interests are being adequately protected."118 A broad view can be taken that the court would draw an inference of participation from financial dealings such as loan covenants and representations used to control a facility's disposal practices. It would be consistent with the holding, however, to extend the reach of the Fleet Factors rule to the use of financial coercion, such as threatening to discontinue future funds, in order to control the facility's actions. Where the survival of a firm is based on future loans, such coercion demonstrates a "capacity to influence."

Fleet Factors leaves lenders with a dilemma. The court stated that a lender "will have a strong incentive to address hazardous waste problems at the facility rather than studiously avoiding the mvestigation and amelioration of the hazard."119 Yet, if a lender can inomitor a facility's hazardous waste disposal practices and thereby reduce the magnitude of potential liability, by doing so the lender accepts the risk of incurring that liability. On the other hand, if the lender constructs a loan agreement so that it cannot monitor the facility's operations, the lender increases the inagnitude of both financial and environmental risks, though it does succeed in avoiding Fleet Factor's "capacity to influence" standard. As a result, the lender is forced to choose between either iminersing itself in its borrower's affairs, or completely detaching itself therefrom.

\section{Indicia of Ownership: Which Lender Interests Are Protected?} Like "participating in the management," the exemption's language "indicia of ownership primarily to protect [a] security interest" 120 also has not been taken at face value. By controlling the forms of ownership protected by the exemption, the phrase acts as a significant determinant of the breadth of the exemption's application. The major disagreenent annong the courts is whether the phrase extends the exemption's protection to actual ownership (acquired through foreclosure, 121 for example) or whether the exemption is limited to a person holding mere "indicia"

(without current environmental problems) instead of refurbishing older but still commercially viable plants that have or are likely to have hazardous waste problems. See infra text accompanying note 261. This policy may also lead to overly cautious lending policies, resulting in unnecessarily high lending costs and delay in the closing of transactions.

118. Fleet Factors, 901 F.2d at 1556.

119. Id. at 1559.

120. CERCLA § 101(20)(A), 42 U.S.C. § 9601(20)(A).

121. Compare United States v. Maryland Bank \& Trust Co., 632 F. Supp. 573, 579-80 (D. Md. 1986) (holding that upon foreclosure the lender's indicia of ownership ripens into full title not protected under the exemption) with United States v. Mirabile, 15 Envtl. L. Rep. (Envtl. L. Inst.) 
of ownership without true title. Either interpretation assumes that the lender holds some form of title to the facility. The title/lien theory interpretation of the exemption supports the latter analysis. ${ }^{122}$

Common law interpretations of "mdicia of ownership" do not require that an owner actually possess physical title to the property. Rather, the common law looks for signs or badges, created by "indicia," that suggest ownership. ${ }^{123}$ The context of the exemption, by protecting owners from hability, suggests that the cominon law ineaning is too broad for direct application to CERCLA liability. What remains unclear is whether forms of ownership protected under the exemption extend to the benefits and risks of private ownership when this ownership is created to capture the value of the security. ${ }^{124}$ This ambiguity comes to light most often when a lender's security interest is transformed imto actual ownership through foreclosure.

A second issue complicates investigations of the types of ownership protected by the exemption: whetlier courts should investigate the actual intent of lenders in lolding ownership in a facility. ${ }^{125}$ The T.P. Long court suggested that foreclosure would not automatically create CERCLA liability because it is a part of the financial aspects of making a loan. ${ }^{126}$ Accordingly, the bankruptcy court broadly defined "indicia of

20,994, 20,996 (E.D. Pa. Sept. 4, 1985) (ruling that foreclosure is protected under the exemption when done "to protect [a] security interest").

122. "Indicia" can be read more broadly to include other financial relationships that are analogous to mortgages in title theory states. See, e.g., In re Bergsoe Metal Corp., 910 F.2d. 668, 669-70, 673 (9th Cir. 1990) (extending the exemption's protection to a lessor that owned property and collected reuts only to ensure the collection of paymeuts on bonds in a related transactiou). In Bergsoe, the court understood the phrase "to protect a security interest" to iuclude not only a borrower's liability to a lender, but also a lender's secondary obligation to bondholders. The Port facilitated the transaction by acting as a lessor of property and was not actually a lender. The bank, which actually held the bonds issued by the Port, was the true lender. The court, however, looking beyond appearances to the substance of the transaction, found that Bergsoe did not hold traditional indicia of ownership (which would presumably trigger liability), and that any residual indicia supported by the Port acting as the lessor were to protect a security interest. See id. at 671.

123. "Indicia" is defined as "[s]igns; indieations. Circumstances which point to the existeuce of a given fact as probable, but not certain." BLACK's LAW DictionaRY 772 (6th ed. 1990). The term "indicia of ownership" is not unique to CERCLA. See, e.g., William W. Bierce, Ltd. v. Hutchins, 205 U.S. 340 (1907). Such interpretatious suggest a distinction between indicia of ownership and actual ownership based on control over the property. Cases such as O'Neil v. Wolcott Mining Co., 174 F. 527 (8th Cir. 1909), suggest that indicia of ownership do not signify actual ownership but rather an apparent iuterest from the point of view of an independent observer. See id. at 531 .

124. See, e.g., supra note 36.

125. Cf. supra text accompanying notes 68-71 (discussing inteut analysis applied to "participating in the management").

126. In re T.P. Long Chem., Inc., 45 B.R. 278, 288-89 (N.D. Ohio 1985). The Mirabile court followed T.P. Long's suggestion that foreclosure was permitted. In so doing, however, it found foreclosure not so much a protected form of ownership as it was a valid type of participation. See 
ownership," stating that "even if [the lender] had repossessed its collateral pursuant to its security agreement it would not be an 'owner or operator' as defined under CERCLA ... [because t] ownership that can be attributed to [the lender] is that which is primarily to protect its security imterest." 127 This broad imterpretation protects lenders' traditional rights in their security interests. ${ }^{128}$ Yet this approach takes the protection of lenders beyond the scope of both CERCLA's innocent landowner defense, which is specifically apphicable to transfers of title, and the language of the exemption itself. ${ }^{129}$

In United States v. Maryland Bank \& Trust Co. ${ }^{130}$ the district court departed from the pro-lender, T.P. Long interpretation of "indicia of ownership."131 The court held that current ownership alone-which existed once the lender, Maryland Bank and Trust (MB\&T), purchased the facility at a foreclosure sale-was sufficient to create CERCLA liability. ${ }^{132}$ Thus, whether or not MB\&T operated the facility or controlled

United States v. Mirabile, 15 Envtl. L. Rep. (Envtl. L. Inst.) 20,994, 20,996 (E.D. Pa. Sept. 4, 1985); supra text accompanying note 90.

127. T.P. Long, 45 B.R. at 288-89.

128. The lenders' interest in the security interest after foreclosure is still linited by federal and state statutory liens. See, e.g., 42 U.S.C. $\$ 9607(l)$ (federal lien); id. $§ 9607(n)$ (nuaritime lien); 11 U.S.C. $\$ \S 507,726$ (state hens and superhens). See generally Douglas C. Ballantine, Note, Recovering Costs for Cleaning Up Hazardous Waste Sites: An Examination of State Superlien Statutes, 63 IND. L.J. 571, 581-83 (1988); Arlene E. Mirksy et al., The Interface Between Bankruptcy and Environmental Laws, 46 Bus. LAw. 623, 688-89 (1991). Proposals for federal superliens have failed to receive adequate support. Ballantine, supra, at 581 (citing H.R. 2767, introduced by Rep. James Florio in 1983).

129. See supra text accompanying notes $24-26$.

130. 632 F. Supp. 573 (D. Md. 1986). For other analyses of Maryland Bank, see David G. Ditto \& Donald M. Gerstein, Comment, Superfund-Your Friendly Hometown Lender? The Liability of Financial Institutions Under the Comprehensive Environmental Response, Compensation and Liability Act, 24 LAND \& WATER L. REv. 493, 505-09 (1989); Gieser, supra note 75, at 667-78; Klotz \& Siakotos, supra note 21, at 312-13; Wilsdon, supra note 75, at 1281-85.

131. See Small Business Hearing, supra note 3, at 3 (statement of Rep. John J. LaFalce) (Because of the Maryland Bank decision and the new innocent landowner defense, "lenders liave become much more careful to inspect property and conduct enviromnental audits before making secured loans and, in general, liave taken a leading role in policing the environmental laws. That may not be a bad thing."). The consequence of the lenders' response was a group of bills in the House and Senate addressing the issues raised by the case. See infra text accompanying notes 217. 54.

132. Maryland Bank, 632 F. Supp. at 577. MB\&T financed McLeod's acquisition of a farm. Unknown to MB\&T, the land had been used for the disposal of hazardous waste approximately eight years prior to the date of the loan. McLeod defaulted on his loan less than one year later. MB\&T foreclosed on its collateral and purchased the property at a foreclosure sale. In 1983, the EPA became aware that the site was contaminated with hazardous waste and required renedial action. Id. at 575. After MB\&T's refusal to clean up the site, MB\&T ultimately settled the case with EPA for more than $\$ 400,000$. See Small Business Hearing, supra note 3, at 15. The EPA expended over $\$ 550,000$ to clean up the site. Maryland Bank, 632 F. Supp. at 575-76. 
the business operations of the borrower, foreclosure by MB\&T triggered CERCLA liability. ${ }^{133}$

The Maryland Bank court limited the scope of the term "indicia of ownership" by only protecting mortgagees who obtained ownership by operation of law but who otherwise were not treated as owners of the mortgaged property. ${ }^{134}$ This holding countered MB\&T's argument, based on Mirabile, ${ }^{135}$ that it was protected by the exemption because it had only purchased the facility at the foreclosure sale with the intent to protect its security interest. ${ }^{136}$ The Maryland Bank court held that once MB\&T purchased the facility, it became the real owner, "not to protect its security interest, but to protect its investinent."137

Although this analysis rejects the T.P. Long/Mirabile intent-based interpretation of "indicia of ownership," by adopting the narrow title/ hen theory approach, the Maryland Bank court exphicitly refused to so reject Mirabile. Instead, the court distinguished Mirabile based on the length of time that the purchased facility was held by the lender. ${ }^{138}$

A recent district court case, Guidice v. BFG Electroplating and Manufacturing Co., ${ }^{139}$ recognized the divergence in the case law between Mirabile and Maryland Bank regarding the exeinption's application upon foreclosure, and determined that Maryland Bank was persuasive. ${ }^{140}$ In Guidice, the court found that the lender, the National Bank of the Commonwealth, had not "passed the point of protecting its security

133. See Maryland Bank, 632 F. Supp. at 577-80.

134. See id. at 579 ("The verb tense of the exclusionary language is critical. The security interest must exist at the time of the clean-up.").

135. See supra note 126.

136. See Maryland Bank, 632 F. Supp. at 579; see also infra text accompanying notes 139-43.

137. Maryland Bank, 632 F. Supp. at 579. The court was influenced by the fact that if MB\&T, as owner of the property, was not held responsible for the cleanup costs, it would receive the benefit of the property cleanup at the expense of the government. See id. at 580 ("[O]nce the property has been cleared at the taxpayers' expense and becomes marketable, the inortgagee-turned-owner would be in a position to sell the site at a profit."). But see Joel R. Burcat, Foreclosure and United States v. Maryland Bank \& Trust Co.: Paying the Piper or Learning How to Dance to a New Tune?, 17 Envtl. L. Rep. (Envtl. L. Inst.) 10,098, 10,100 (1987) (arguing that because of transactions and other associated costs lenders will receive little benefit even if value of the property is imcreased by an EPAsponsored cleanup). The EPA Proposed Ruling, see infra text acconpanying notes 188-89, responded to this concern. Under the Ruling, the difference between the nuarket value of the parcel of land after cleanup and the value of the property in its contaminated condition could be sought by the EPA under equitable reimbursenient. However, imder the Ruling, this provision would only apply to situations in which the EPA performed the cleanup while the lender still held its indicia of ownership (i.e., was still a secured creditor), which was not the situation in Maryland Bank.

138. See Maryland Bank, 632 F. Supp. at 580.

139. 732 F. Supp. 556 (W.D. Pa. 1989).

140. See id. at 563. Local residents of Punxsutawney, Pennsylvania sued BFG for response costs under CERCLA and for personal injury damages caused by environmental contamination. BFG then filed a third-party complaint against the current and past owners of an adjacent property known as the Berlin Property, including the National Bank of the Cominonwcalth, for indemnification, 
interest" by participating in the management or control of the facility prior to foreclosure. By foreclosing on the containinated property, however, National became the actual owner of the property and was not protected by the secured creditor exemption. ${ }^{141}$ In addressing the issue of hability stemming from National's foreclosure, the Guidice court followed the lead of Maryland Bank. ${ }^{142}$ The Guidice court held that once National had foreclosed, it was no longer protected by the secured creditor exeinption and was "hiable to the same extent as any other bidder at the sale would have been."143

contribution, and response costs from the owners. National foreclosed on its mortgage on the Berlin Property, and held title for eight months before reselling. Id. at 558-59.

141. Id. at 561-63. In Guidice, there had been a continuous discharge of hazardous waste at a facility, suggesting that hability could be imposed on persons who held an ownership interest during such surreptitious discharges: "[E]ven though there was no active management here, the toxic stew was nonetheless percolating and that fact was enough to trigger potential liability." Hearing on H.R. 4494, supra note 53, at 53 (statement of Rep. Norman F. Lent of New York).

The Guidice holding highlights the temporal distinction between foreclosing on a security interest and purchasing the property at a foreclosure sale. A lender, by foreclosing, simply exercises a right to force a statutory sale of property securing a debt. Foreclosure does not change the status of a lender's ownership interest. It is only the purchase of the facihty that gives a lender actual ownership. During the interim period betwecn foreclosure and purchase, a lender may act as a trustee, holding the land for the court. See Small Business Hearing, supra note 3, at 113-14 (statement of Charles M. Mitschow, American Bankers Association). In this role as a trustee, a lender inay have to take affirmative actions to protect and maintain the property. The Guidice decision suggests that active participation during this interim period can create liability, although the facts of this case did not indicate such liability.

The court in Guidice also relied on congressional (in)action to support its conclusion: The SARA amendments restricted the definition of owner and operator by exempting state and local governments acquiring "ownership or control involuntarily through bankruptey, tax delinquency, abandonment, or other circumstances in which the government involuntarily acquires title by virtue of its function as sovereign." CERCLA $\S 101(20)(D), 42$ U.S.C. $\$ 9601(20)(D)$; see also 131 CONG. REC. H11,157-62 (daily ed. Dec. 6, 1985), reprinted in 5 A LEgisLATIVE HistoRY OF THE SUPERFUND AMENDMENTS AND REAUTHORIzATION ACT OF 1986, Public LAw 99-499, at 4140. 50 (Comm. Print 1990). Recognizing this, the court noted "[t]hat Congress did not simultaneously amend the statute to exclude from liability lenders who acquire property through foreclosure" and that this "might indicate that Congress intended to hold [lenders] liable as owners." Guidice, $732 \mathrm{~F}$. Supp. at 563 (citing Tom, supra note 113, at 926); Coastal Casting Serv., Inc. v. Aron, Civ. A. No. H-86-4463, 1988 WL 35012 (S.D. Tex. Apr. 8, 1988). But see Madden, supra note 64, at 144 n.67 ("[T] he [Guidice] court's interpretation begs the question of what Congress mcant when it included an exemption for secured creditors in CERCLA. It should also be noted that the Maryland Bank \& Trust decision, which indeed might have given Congress reason to exempt landowning lenders specifically, was decided after the substantive markup of SARA had been completed.").

142. See Madden, supra note 64 , at $143-44$.

143. Guidice, 732 F. Supp. at 563. The court stated that when Congress created the secured creditor exemption, it could have, but did not, "exclude from liability lenders who acquire property through foreclosure," and that by not doing so, it "might indieate that Congress intended to hold [lenders] liable as owners." Id. (citation omitted). 


\section{THE EPA TURNS TAIL}

The EPA has until recently sought to impose stringent lender hability standards in the courts. Bowing to pohtical pressure froin both lenders and advocates for federal agencies, however, the EPA recently proposed a ruling that reversed its hard-line position. ${ }^{144}$ The EPA Proposed Ruling urges specific pro-lender interpretations of both the secured creditor exemption and innocent landowner defense. ${ }^{145}$

The Ruling attempts to provide guidance and the illusion of certainty to lenders by defining the exeinption's ambiguous terms: "indicia of ownership," "primarily to protect the security imterest," and "participatimg in the management."146 The Ruling, however, does more than simply resolve such ambiguities; it represents a policy statement in which the EPA lias designed a balance between lenders' roles in the financing industry and with regard to the environment. ${ }^{147}$ To advance its policy,

144. National Oil and Hazardous Substances Pollution Contingency Plan; Lender Liability Under CERCLA, 56 Fed. Reg. 28,798 (1991) [hereinafter EPA Proposed Ruling] (to be codified at 40 C.F.R. pt. 300) (proposed by EPA, June 24, 1991). The current version represents the first official release, although it is actually the third draft. The first two drafts were issued by the EPA on September 14, 1990 and January 24,1991, and though unofficial, were subsequently printed in a “bootleg” form. See 55 Banking Rep. (BNA) 636 (Oct. 15, 1990); 56 Banking Rep. (BNA) No. 8, at 372 (Feb. 25, 1991).

145. With respect to the innocent landowner defense provisions, see supra note 23. The EPA chose to interpret specifically the language "government entity which acquired the facility . . . tlirough any ... involuntary transfer or acquisitiou," id. $\$ 101(35)(\mathrm{A})(\mathrm{i}), 42$ U.S.C. $\S 9601$ (35)(A)(ii), so as to protect a wide range of governmental acquisitions. The language specifcally defined "government[al] eutity" to iuclude "governmental lending and credit institutions, loan guarantors, and financial regulatory entities which acquire security interests or properties of failed private lending and depository institutious." EPA Proposed Ruling, 56 Fed. Reg. at 28,809-10. Thus, consistent with its goal to pacify political pressure related to financial institution failures, see supra notes 29-35 and accoinpanying text, the EPA responded to fears that the FDIC and RTC could be threatened by unlimited environmental liability merely by following the mandate of their respective governing legislation.

146. See EPA Proposed Ruling, 56 Fed. Reg. at 28,802. According to the EPA, the Ruling is being promulgated "to specify the range of permissible actions that may be undertaken by lolders of a security interest within the bounds of the section 101(20)(A) security interest exemption." Id. at 28,799 . The Ruling still may not solve the problem. One lawyer correctly observes that the Ruling is not going to provide the kind of certainty that lenders will require in order to feel comfortable entering into envirounentally risky loans: "If the best [that can be done] is [to] say that there is au interpretive rule which a court may [or may not] look to, then ... [one] would liate to be the lender's counsel who [is] the first . . . to test [the] theory." Hearing on H.R. 4494, supra note 53, at 107 (statement of James P. O'Brien).

147. The EPA certainly lad an idea of what it wanted to accomplish with the Ruling: "Clearly, bankers acting as bankers should not be liable under environmental statutes. On the other liand, any entity acting as a lazardous waste operator, including banks, sloould face liability under carefully defined circuinstances." Hearings on H.R. 4494, supra note 53, at 36 (statement of James M. Strock, EPA). In the EPA's own words, the Ruling "seeks to reconcile a security lolder's need to manage, oversee, or to otherwise act to protect a security interest, with the EPA's duty to clean up waste sites and recover public funds spent in remediating these sites from those responsible or otherwise involved in the facility's operations ...." EPA Proposed Ruling, 56 Fed. Reg. at 28,800. 
however, the EPA creates a precarious and uncertain balance that departs from the exemption's intent and language. The Ruling succeeds to the extent that it demonstrates the EPA's current view on lender liability through the most comprehensive proposal for a resolution of the problem to date. Ultimately, the Ruling will fail because the degree to which the courts will defer to the EPA's judgment in this matter is unclear. ${ }^{148}$

\section{A. Interpreting the Secured Creditor Exemption}

1. The EPA's Interpretation of "Indicia of Ownership." The Ruling defines "indicia of ownership" to include "interests in real or personal property held as security for a loan or other obligation." 149 The term specifically includes actual legal title to property (real or personal) acquired incident to foreclosure or its equivalents, depending on the laws of the different states. A non-exhaustive hist of valid forms of ownership is included: "a mortgage, deed of trust, or legal title obtained pursuant to foreclosure or its equivalents, or an assignment, hen, pledge, or other right to or form of encumbrance against property that is legally recognized as establishing a bona fide security interest."150 These illustrations of protected "indicia of ownership" indicate that the EPA has adopted an interpretation of the term similar to T.P. Long's intent-based approach. ${ }^{151}$ Additionally, they exhibit a surprising characteristic: They include legal relationships between a creditor and the creditor's security that can not be classified as "indicia of ownership."152 In light of the EPA's intent-based approach and its overly broad definition of the exemption, any suggestion that the EPA is interpreting the secured creditor exemption cannot be supported. Rather, the Ruling simply represents the EPA's own enforcement pohicy with regard to lenders, secured or not.

2. The EPA's Interpretation of "Primarily to Protect a Security Interest." The EPA's intent-based approach is derived from the exemption's phrase "primarily to protect a security interest." The Ruling's definition of the phrase equates that language with "for the purpose of

148. See infra notes $193-216$ and accompanying text.

149. EPA Proposed Ruling, 56 Fed. Reg. at 28,802 (to be codified at 40 C.F.R. pt. 300.1100 (a)).

150. Id. Presumably, inclusion of this "bona fide security interest" language is meant to exclude from the exemption lenders who hold the interest in the contaminated property for investment, a provision that was specifically included in the original draft.

151. See supra text accompanying notes 125-29.

152. See supra note 123. Most notably, the Ruling fails to distinguish between title and lien mortgages. In the latter, where no "indicia of ownerslip" exist, ownership liability is only possible upon foreclosure. Without sucl action, the EPA would need to prove that the lender was an operator, as opposed to proving that it participated in management. 
securing payment or performance of an obligation."153 This approacl1 draws a line between protecting a "security interest," which the EPA would allow under the exemption, and simply lolding an ownership interest for "imvestment" purposes, which is not permitted and which would subject the lender to CERCLA hability as an owner. This line between security interests and investments conforms witl the title/lien theory approach, which distimguishes between true lenders and owners who use a sham lending entity to avoid CERCLA liability.

Yet, because lending is a form of investment, the security/mvestment distinction is not as clear as the EPA might hope: Banks do not lend money out of a social duty, but instead through a desire to profit from the transaction. ${ }^{154}$ In light of the ambiguous nature of lender imvolvement, the Ruling retreats somewhat from a bright-line security/investment distinction by explicitly recognizing that lenders "typically have revenue interests in tlic loan transactions,"155 but nevertlieless retains the essence of an exempted transaction as the assurance of repayment of the loan. This practical distinction seems inore appropriate than Congress's use of "participation in the management" to distinguish lenders from investors. 156

The EPA's distinction, however, becomes blurred witl respect to lease transactions. As demonstrated by Bergsoe, leases sometimes liave the characteristics of a secured loan. ${ }^{157}$ The Ruling "recoguize[s that] forms of security interests include . . . some forms of leases or consiguinents. ..."158 Whether or not the exemption actually applies to such an arrangement, lowever, depends on the "facts of each case,"159 a standard

153. EPA Proposed Ruling, 56 Fed. Reg. at 28,808 (to be codified at 40 C.F.R. pt. 300.1100 (b)).

154. One commentator suggests that:

[I]f the loan seeks merely to protect the lender from market risks, then it should not be considered grounds for lender liability under CERCLA. On the other hand, if the equity participation is structured in such a way that it includes a return on an ownership interest, then the lender should be held jointly and severally hable as an owner or operator under CERCLA. ... O Ownership risk is different from market risk. ... A potential higher rate of return is provided to an ownership interest because ownership implies added risk and responsibility.

Robin P. Malloy, Equity Participations and Lender Liability Under CERCLA, 15 CoLUM. J. ENVTL. L. 63, 76-77 (1990).

155. EPA Proposed Ruling, 56 Fed. Reg. at 28,802 .

156. This fine line unay lose its distinction, however, in complex transactions in which a lender obtains interests to secure botlı debt and equity interests. Malloy, supra note 154, at 71-75.

157. See In re Bergsoe Metal Corp., 910 F.2d. 668, 671 (9th Cir. 1990) ("The Port is in somewhat of a different position than the ordinary secured creditor .... The Port held title ... not to ensure that it would receive payment, but to guarantee that [the lessee] would cover the Port's own indebtedness .... . This does not change the analysis.").

158. EPA Proposed Ruling, 56 Fed. Reg. at 28,802 .

159. Id. at 28,802 n.4. 
that presumably requires an investigation into "whether a security interest arises under applicable law, regardless of the label given to the particular transaction." 160 Unfortunately for the lender, the inquiry into the facts of eacli case creates the same uncertainty that has constantly plagued the exemption.

3. The EPA's Interpretation of "Participating in the Management." The central objective of the Ruling is to remove the uncertainty that pervades CERCLA lender liability law. ${ }^{161}$ To do this, the Ruling specifies whetler certain actions, sucl as "monitoring facility operations, requiring compliance activities, refinancing or undertaking loan workouts, providing financial advice, and similar actions that may affect the financial, manageinent, and operational aspects of a business" 162 constitute participation in the management of a particular facility. Under the Ruling, "participation in the nanagenent of a facility" means:

actual participation in the management or operational affairs by the holder of the security interest, and does not include the mere capacity, or ability to influence, or the unexercised right to control facility operations. A security holder is considered to be participating in manageInent if, while the borrower is still in possession, the security holder is either: (i) exercising decisionmaking control over the borrower's environmental comphiance ...; or (ii) exercising control at a manageinent level encompassing the borrower's environmental compliance responsibilities . . . . 163

This language explicitly rejects the Fleet Factors "capacity to influence" language, and instead looks for certaim forms of active involvement with a borrower before imposing liability. Moreover, the participation must be related to the facility's environmental compliance. Thus, the EPA rejects the title/lien theory approach to the exemption even though it formally acknowledges this approach in its review of the exemption's legislative history. ${ }^{164}$ Instead, the EPA lias approved of the application of the exeniption as a defense for participation, ratler than as a determinant of ownership. Furtler evidence of this is demonstrated in the Ruling's occasional lapse into T.P. Long's intent-based standard for participation.

160. Id. at 28,802 . As to the "applicable law," the most common state-law definition of a security interest is that found in the Uniform Commercial Code. See U.C.C. \$ 1-201(37) (1990) ("Security Interest' means an interest im personal property or fixtures which secures payment or performance of an obligation. ... Whether a transaction creates a . . . security interest is determined by the facts of each case.").

161. EPA Proposed Ruling, 56 Fed. Reg. at 28,799.

162. Id. at 28,798 .

163. Id. at 28,809 (to be codified at 40 C.F.R. pt. 300.1100 (c)(1)); $c f$. 56 Banking Rep. (BNA) No. 8, at 378 (Feb. 25, 1991) ("[T]he [lender] has materially divested the borrower of, or otherwise is engaged in, decisionmaking control ....”.).

164. See EPA Proposed Ruling, 56 Fed. Reg. at 28,799 . 
For example, the Ruling states that "[f]or purposes of this proposed rule, mitigative or preventative measures that are environmentally responsible are considered to be actions that preserve and protect the value of the facility and, hence, protect the security interest. Accordingly, such actions are not considered evidence of participation in manageinent."165 This statement indicates that even when participation is otherwise sufficient to nullify the exemption, such participation does not nullify the exemption if done with the intent to protect the security interest.

Ideally, if only to protect its own investment, one would want a lender to be free to encourage responsible decisionmaking regarding the nature of the cleanup required by the borrower and to take appropriate response action if a problem develops. The Ruling attempts to hold the lender hable only when it directly contributes to the harm caused to the environment. ${ }^{166}$ Yet, the Ruling does not specify whether a lender loses the exemption's protection forever once it has participated in manageinent. This ambiguity needs to be resolved. ${ }^{167}$ To be consistent, the Ruling should allow a lender to reestablish its protected status under the exemption. To do otherwise would penalize a lender for accepting the risk of CERCLA liability in order to address a hazardous waste threat.

In Fleet Factors, the Eleventh Circuit suggested that lenders are in a unique position to police the hazardous waste practices of borrowers. At the same time, however, the court failed to clarify wliether a lender could pursue this policing function without incurring liability. The Ruling directly addresses this problem by providing examples of activities that would not be considered "participating in the inanagenent of a facility,"

165. Id. at 28,805 .

166. For example, if a lender had exercised enough control to be considered to have participated in the management of a facility for certain actions (such as the cleanup of certain, discrete waste) but subsequent to that cleanup, the business causes a spill to occur without participation of the lender, the lender should not be held liable even though it had participated in the management for certain aspects of the activity. This situation would encourage the lender to protect its security interest and thereby also protect the environmental condition of the property, without subjecting itself to unlimited liability for the remainder of the company's operations.

167. Additionally, although the Ruling rejects Fleet Factors" "capacity to influence" standard, it does not address whether a lender can actively employ such capacities without participating in management. Thus, a borrower, possibly through economic leverage imposed by the lender, might "decide" to change its hazardous waste practices to conform to the lender's wishes. If this occurred, presumably the purposes of CERCLA would be furthered by the realization of more responsible environmental business practices. But to what extent would the decision be attributed to the financial institution as a coerced choice? The lender would have directed the borrower's decisions regarding treatment and disposal of hazardous waste. This indicates an area of uncertainty that the lenders must be aware of, and an area that the Ruling should, but fails to address satisfactorily. 
including various activities at the inception of the loan, policing the loan, participating in "loan workout," and foreclosing on the assets. 168

a. Actions at the loan inception. The Ruling indicates that any and all activities undertaken by a lender "prior to or at the inception of a security interest are not considered evidence of participation in unanageinent that would void the exemption."169 In addition to typical negotiations regarding the structure, terms, and timing of the agreement, as well as financial advice and counseling, a lender may require an environinental inspection as a precondition to the loan. ${ }^{170}$ The Ruling is careful to note that such an inspection is not required to benefit from the exemption, ${ }^{171}$ and liability of a security holder cannot be based on either requiring or failing to require such an inspection. ${ }^{172}$

If such an inspection reveals contamination, a security holder may respond in several ways, none of which the EPA would consider to be "participating in the manageinent of the facility." These options include refusing to extend credit; requiring that the borrower clean up the facility as a condition to receiving the loan; ${ }^{173}$ and once the determination has been made that either the extent of the contamination is ininimal and does not significantly affect the value of the facility, or that the risk of

168. See EPA Proposed Ruling, 56 Fed. Reg. at 28,803-06. Regardless of the label associated with a lender's actions, however, a lender that causes or contributes to the release or threat of release of a hazardous substance while interacting with a facility is not necessarily protected by the exemption, because such actions inay result in independent operator liability. If actions taken to protect the security interest do cause or contribute to a release, the effect on the exeinption is irrelevant, because the party cansing the release will be subjected to CERCLA liability under provisions independent of the secured creditor exemption. See CERCLA § 107(a), 42 U.S.C. § 9607(a).

169. EPA Proposed Ruhing, 56 Fed. Reg. at $28,803$.

170. Id. at 28,803-04.

171. A secured holder would be well advised to undertake this obligation because an environmental inspection is consistent with the remedial purposes of CERCLA, and because an inspection may identify contaminated property that presents a risk to human health and the environment. Also, although the holder of the security interest is not required to perform an environmental inspection of the property, a sophisticated purchaser of property is required to do so to qualify for the innocent landowner defense. See CERCLA $\S \S 107(b)(3), 101(35)(B), 42$ U.S.C $\S \S 9607(b)(3)$, 9601(35)(B).

172. The first draft of the Ruling required an inspection of the property to qualify for the secured creditor exemption. 55 Banking Rep. (BNA) 638 (Oct. 15, 1990). The second draft, although not requiring an environmental inspection of property securing the loan, nevertheless treated such an inspection as "a badge of good cominercial practice and an indicia of responsible behavior under [CERCLA]" that provided highly probative evidence of actions consistent with the exemption. 56 Banking Rep. (BNA) No. 8, at 379 (Feb. 25, 1991).

173. This requirement may actually impede the overall goals of CERCLA when a company desires to clean its property of hazardous waste and needs the loan in order to do so. 
default is low, proceeding to take a security interest in the contaminated property. ${ }^{174}$

b. Policing the loan under the EPA Proposed Ruling. Once a transaction commences, and without "participating in the management," a security holder may police the loan consistent with protecting his security interest. In doing so, a lender may periodically momtor or inspect both the borrower's facility (including on-site inspections and audits) and his business and financial condition, require clean up of the site during the hife of the transaction, ${ }^{175}$ and require a contractual assurance of the borrower's compliance with all apphicablc environmental laws.

c. Loan workouts. The next step in protecting the security interest occurs if the borrower is liaving difficulty in ineeting the required payments on the secured transaction, and the loan is thereby either in threat of, or actually is in, default. Actions to address this problem are commouly referred to as "loan workout" activities, 176 and involve "effort[s] to prevent default of the loan or diminution of the value of the security."177 Workouts, which represent an important area of concern for lenders, are protected by the Ruling's interpretation of tlie exemption. Sucl1 protection exists, however, only while the borrower remains the "ultimate decisionmaker" for operation of the facility. ${ }^{178}$

174. See EPA Proposed Ruling, 56 Fed. Reg. at 28,804. This provision, however, seems troublesome because knowingly taking an interest in a contaminated property is a different situation from that of an unknowing lender who discovers that his already acquired security on a loan is practically worthless. However, under the exemption, as long as the holder acts to protect his security interest without participating in the management, the property's contamination is irrelevant to the lender's liability. This would change if the lender cannot dispose of the property after foreclosure, a property that the lender knew was contaminated even before entering into the loan transaction. $C f$. United States v. Fleet Factors Corp., 901 F.2d 1550, 1558 (11th Cir. 1990) (imposing a rule designed to give incentives to lenders to police loans), cert denied, $111 \mathrm{~S}$. Ct. 752 (1991).

175. In such a scenario, the lender, by taking an "active" role, appears to be directly in conflict with the commentary's language requiring the borrower, not the lender, to remain "substantially in control" of the business. This situation illustrates the difficulty of line-drawing in this area.

176. What would nonnally be included in a "workout" differs from state to state and among flnancial institutions. " $A$ workout is a situation where you have a delinquent loan and you are trying to work with the borrower to restructure the loan to avoid foreclosure and taking possession of the property, or avoid forcing the borrower to take bankruptcy." Hearing on H.R. 4494, supra note 53, at 67 (statement of David C. Cooke, RTC). "[I]f you ask 20 different loan workout officers from banks what their job was or what the term ineans, [you] would probably get 20 different definitions." Id. (statement of Steven A. Seelig, FDIC).

177. EPA Proposed Ruling, $56 \mathrm{Fed}$. Reg. at 28,804. Permissible actions include restructuring or renegotiation of the terms of the loan, e.g., "requiring payment of additional interest, extension of the payment period," and giving "specific financial or operational advice, counseling, [or] guidance." Id.

178. Id. Both earlier drafts of the Ruling contained the requirement that in order to maintain the protection of the exemption, the holder must ensure, consistent with the "participating in the management" standard, that "the borrower remains substantially in possession and control of the 
d. Foreclosure on the security interest. The Ruling rejects the Maryland Bank/Guidice approach under which foreclosure creates true ownership not protected by the exemption. ${ }^{179}$ Instead, the Ruling permits foreclosure if "reasonably necessary to ensure satisfaction or performance of the [loan] obligation."180 Thus, a lender may temporarily acquire possession of the borrower's collateral through any one of several methods, includimg foreclosure, ${ }^{181}$ while maintaining protection under the secured creditor exemption.

Once the lender lias acquired possession of the property, it must "act to preserve the assets of the facility" for its subsequent sale, ${ }^{182}$ and inust endeavor to maximize the value of the secured asset to realize the debtor's unpaid obligation. Actions to mitigate environmental liarm are not considered by the EPA to be evidence of participation in management, as long as the actions taken are considered to be "environmentally responsible."183 To maintain the exemption's protection, a security lolder need not dispose of the property within a specified period of time. ${ }^{184}$ However, it inust begin to advertise (on a inonthly basis) the property for sale in an appropriate publication within twelve inonths of foreclosure. ${ }^{185}$ Further, the security holder inust neither reject nor fail to act on a "written, bona fide, firm offer" of "fair consideration" for the

operations of the facility ... [and] continues to make operational decisions at the facility." 56 Banking Rep. (BNA) No. 8, at 378-79 (Feb. 25, 1991) (emphasis added); 55 Banking Rep. (BNA) 638 (Oct. 15, 1990) (same language). Even though the word "substantially" was removed before thc formal release of the Ruling, 56 Fed. Reg. at 28,803 , this standard will continue to require judicial clarification, since the "control" standard is not a simple, bright-line test that would clarify where lenders stand, but instead represents a spectrum where the point at which liability is incurred is unclear.

179. See supra text accompanying notes $130-43$.

180. EPA Proposed Ruling, 56 Fed. Reg. at 28,805 .

181. See id. The EPA's interpretation that foreclosure is not a root of liability is consistent with other readings of CERCLA: "Congress, in enacting Superfund in 1980, never intended to hold lenders liable when they foreclose on contaminated property ... [and] therefore recent court decisions holding such lenders liable stand in direct violation of Congressional intent." Hearing on H.R. 4494, supra note 53, at 14 (statement of Rep. John J. LaFalce).

182. EPA Proposed Ruling, 56 Fed. Reg. at 28,805. Although "winding-up" operations at a facility is consistent with the exemption, the Ruling also provides that a "security holder may deterinine a need to undertake certain actions with respect to a facility's operations in order to preserve the value of the foreclosed-on assets or to prevent a future release ...." Id. Whether or not this includes actual operation of a facility for a limited period of time is unclear. Arguably, as long as operation was reasonably necessary to secure the property for sale, then the actions would be covered; yet protecting actual operation of a facility conflicts with the act's language.

183. See id.

184. Id. at $28,805-06$.

185. Id. 
property. ${ }^{186}$ Failure to meet this standard would suggest that the property was being held for some purpose other than to protect the security interest, and therefore the protection of the exemption would be lost. ${ }^{187}$

The EPA maintains that any conduct on the EPA's part in cleaning up a site should not benefit the security holder. ${ }^{188}$ Should the EPA's actions enhance the value of the secured property, the Ruling will permit the EPA to seek equitable reimbursement of the amount that unjustly enriched the security holder. ${ }^{189}$

4. The EPA Proposed Ruling: Conclusions. The EPA Proposed Ruling has three significant problems. ${ }^{190}$ The first concerns the lack of a shelter rule for subsequent purchasers to transfer the immumity enjoyed by governmental entities and security holders with the property. Without such a rule, parties will be hesitant to purchase the facility from the lender, because to do so would expose them to CERCLA hability. ${ }^{191}$ Lenders, therefore, although receiving broader protection from liability, will be unable to capture value from their security imterests through sale of the property until the prolonged task of restoring and cleaning up the site is accomplished.

186. Id. "Fair consideration" is defined as "an amount equal to or in excess of the sum of the outstanding principal owed to the holder, plus any unpaid interest and penalties ..., plus all reasonable and necessary costs...." Id. at 28,809 . In other words, the security interest is designed only to secure the amount that the bank has "invested" in the transaction.

187. Id. at $28,805-06$.

188. Id. at 28,806 ("In the event that EPA conducts a response action at a facility during the time that a security holder mamtains indicia of ownership to protect a security interest, pursuant to CERCLA [\$] 107(l), 42 U.S.C. [\$] 9607(l), a lien in favor of the Umited States may be imposed.").

189. The EPA could recover the excess amount realized by the security holder at the foreclosure sale over "that to which the security holder is entitled under rules of equity." Id. at 28,806 . It is unclear whether this ineans an amount over the uurecouped amount of the original loan plus expenses, as defined in the "fair consideration" provision, whether it ineans any increase in inarket value over that of the property at the time of foreclosure, or whether it means that the equity rules of each state apply, thereby encouraging forum shopping. Regardless, the provision is in essence a federal superlien. See supra note 128. The language contained in the comments to the first draft made the EPA's intent clear as to this issue: The lender is limited to the value of the contaminated property at the time of foreclosure; and thus is not guaranteed a full return of its loan. Any increase of the market value of the property due to EPA action over its inarket value in the containimated condition is recoverable by the EPA under equitable reimbursement. 55 Banking Rep. (BNA) 639 (Oct. 15, 1990). The basis of valuation, however, is not stated in any of the drafts.

190. More minor problems with the Ruling include its failure to address concerns in connection with trust and fiduciary activities, and concerns regarding potential liability under RCRA. See generally Bank Witnesses Endorse Legislation over EPA Rule to Address Lender CERCLA Liability, 56 Banking Rep. (BNA) No. 24, at 1132 (June 17, 1991).

191. Witlout such protection, "purchasers will either shy away from buying . . containinated properties, or will ask for significant price cuts to account for the risk." Id. (remarks of L. Williain Seidman, FDIC). 
Second, the Ruhing is subject to the fluctuating political environment that created it: As the banking crisis subsides and lenders' political clout diminisles, a new, "correct" interpretation of the exemption could be establislied by the EPA. Thus, imstead of being a panacea for lenders, the Ruling merely clianges the game. Lenders still face significant liability and uncertainty in legal doctrine. What the Ruling does do is arguably diffuse any legislative concern, thereby threatening the postponement of needed congressional action.

Third, the Ruling does not address state environmental laws that play a similar role to the federal CERCLA. There is no provision for preemption of these laws and therefore, even if the Ruling is granted deference by the courts, the Ruling would have no effect on how state CERCLAs are interpreted. Thus, lenders would be faced with the same degree of liability as before the promulgation of the Ruling, but this time it would ouly be under state law, ratler than under both federal and state laws styled after CERLCA. ${ }^{192}$

\section{B. Potential Judicial Reaction to the EPA Proposed Ruling 193}

An overarching problem for the EPA Proposed Ruling is that its binding effect, if finally adopted, remains unclear. The issue is complicated by the fact that although the EPA is explicitly interpreting the secured creditor exemption, ${ }^{194}$ the EPA claims to be promulgating a legislative rule ${ }^{195}$ under autliority of specific sections of CERCLA. ${ }^{196}$ It is not clear, however, that the autliorizing language actually permits promulgation of the Ruling. ${ }^{197}$ The courts will have the final say on low to

192. See Small Business Hearing, supra note 3, at 93 (statement of Michael Dore) (The "issue of federal preemption is perhaps as crucial ... as the determmation of the precise basis of liability to be imposed upon financial institutions."); infra text accompanying note 250.

193. An im-depth analysis of the administrative law issues raised by the EPA's promulgation of the Ruling is beyond the scope of this Note. The following discussion is provided to draw some of the issues to the reader's attention, and to demonstrate that because uncertainty pervades the judicial review process of such administrative rules, lenders will contmue to face uncertainty if the Ruling is adopted.

194. See EPA Proposed Ruling, 56 Fed. Reg. at $28,798$.

195. Informal (notice-and-comment) rulemaking is provided for in the Admimistrative Procedure Act, 5 U.S.C. $\$ 553$ (1988).

196. The EPA issued the Ruling inder CERCLA sections 105 and 115, which authorize the executive to issue and revise the National Contingency Plan (NCP) from time to time. EPA Proposed Ruling, 56 Fed. Reg. at 28,799; see also CERCLA $\S \S 105,115,42$ U.S.C. $\S \S 9605,9615$.

197. Although sections 105 and 115 may not provide authority for promolgnting the entire Ruling, CERCLA may provide alternative authority for parts of the Ruling. Under section 107(d), parties who provide advice pursuant to the NCP (and, by implication, who investignte or monitor facilities to form a basis for the advice) are shielded from liability for damages resulting from actions taken or omitted in the course of rendering such advice, unless grossly negligent. CERCLA 
treat the Ruling, whether it is legislative or interpretive, ${ }^{198}$ and what degree of deference to give to the Ruling. 199

Section 105 of CERCLA authorizes the EPA to promulgate rules that "reflect and effectuate the responsibilities and powers created" by CERCLA, and "to establish procedures and standards for responding to releases of hazardous substances."200 The latter provision specifically calls for the specification of "procedures, techniques, materials, equipment, and methods to be employed in identifying, removing, or remedymg releases of hazardous substances ...."201 Section 115 broadly grants the EPA power to "promulgate any regulations necessary to carry out the provisions of this subchapter."202 Although broad, this language arguably only authorizes the EPA to promulgate legislative rules to specify how to realize Congress's intent. It does not grant to the EPA the power to define substantively who does and who does not fall within CERCLA's liability scheme, an issue that goes to the very heart of the EPA's jurisdiction. ${ }^{203}$ Specifying liability standards is Congress's responsibility

§ 107(d), 42 U.S.C. § 9607(d). Unlike the EPA's approach to interpreting the secured creditor exeinption, section 107(d) provides direct rulemaking authority in connection with a "liability" section: By establishing the minitnum provisions of the NCP with regard to identifying and reducing the threat of hazardous waste releases, id. $\S 105(1)-(2), 42$ U.S.C. $\S 9605(1)-(2)$, the EPA might amend the NCP to permit or require persons associated with the facility to provide such advice.

198. Because this is not the typical situation where an administrative agency acts pursuant to a carte blanche grant of authority by Congress to pronulgate rules in an area, but instead is an attempt to interpret actual legislative language in a binding rule, the standard of review is unclear. For an overview of judicial review of both legislative and interpretive rulemaking, see KENNETH CULP Davis, Administrative Law Treatise $\S \S 29.16,29.20$ (2d ed. 1984). See also Robert A. Anthony, Interpretive Rules, Policy Statements, Guidances, Manuals, and the Like-Should Federal Agencies Use Them to Bind the Public?, 41 DUKE L.J. (forthcoming June 1992) (suggesting the vagueness of the definition of a legislative rule). The first case to challenge the Rulimg is already in the pipeline. See Atlantic Richfield Co. v. Oaas, No. CV-90-75-BU-PGH (D. Mont. filed Jan. 21, 1992); Company Says No Deference Due EPA Letter as Secured Lender Exemption Won't Apply, Banking Daily (BNA), Mar. 6, 1992, available in LEXIS, BNA Library, BNABD File.

199. If the EPA does not have authority to promulgate the Ruling, the failure to challenge the Ruling in the Court of Appeals for the District of Columbia Circuit, CERCLA § 113(a), 42 U.S.C. \$ 9613(a), within a 90-day period should not preclude a successful challenge during future hitigation. See EPA Proposed Ruling, 56 Fed. Reg. at 28,800; see also Richard J. Pierce, Jr., Two Problems in Administrative Law: Political Popularity on the District of Columbia Circuit and Judicial Deterrence of Agency Rulemaking, 1988 DuKE L.J. 300, 327 (suggesting that the District of Columbia Circuit takes a conservative though problematic approach to grantimg deference to agencies).

200. CERCLA $\S 105,42$ U.S.C. $\S 9605$.

201. Id.

202. Id. § 115,42 U.S.C. $\S 9615$.

203. Some commentators argue that Chevron deference analysis, see infra notes $205-09$ and accompanying text, is simply not applicable to a situation where basic jurisdictional issues witl respect to an agency are involved. See CASS R. SUNSTEIN, AFTER the RightS REvolution: ReCONCEIVING THE REGULATORY STATE 142-44 (1990) (arguing against a general rule of judicial deference to all agency interpretations). But see Dole v. United Steelworkers of Am., 494 U.S. 26, 46 (1990) (White, J., dissenting); Mississippi Power \& Light Co. v. Mississippi ex rel. Moore, 487 U.S. 354, 380-82 (1988) (Scalia, J., concurring in judgment). 
alone. ${ }^{204}$ Thus, since the Ruling specifies the extent of conduct acceptable under the secured creditor exemption, and what conduct would expose the lender to liability, the Ruling cannot be regarded as binding, because it is proinulgated without autliority.

Accepting, arguendo, the premise that the Ruling is not binding on the courts, the Ruling could still be treated by the courts inerely as an interpretive rule entitled to modern deference analysis under Chevron USA, Inc. v. Natural Resources Defense Council, Inc. ${ }^{205}$ In Chevron, the Supreme Court lield that when "Congress has directly spoken to the precise question at issue," courts "must give effect to the unambiguously expressed intent of Congress." 206 However, if the statute in question is "silent or ambiguous witl respect to the specific issue,"207 and therefore, no clearly expressed congressional intent is ascertainable, then courts should defer to an agency's interpretation of a statute for which the agency is responsible if the agency's interpretation is based on a "permissible" or reasonable construction of the statutory language. ${ }^{208}$ Judicial application of this doctrine, lowever, is by no means clear, as evidenced by opimions of the Supreme Court. 209

204. Section 105(a)(9), the only section which arguably authorizes the Ruling, reads: "The President shall [have authority to] specify] roles for private organizations and entities in preparation for response and in responding to releases of hazardous substances, including identification of appropriate qualifications and capacity therefor . . .." CERCLA $\$ 105(a)(9), 42$ U.S.C. $\$ 9605(a)(9)$. This language cannot be stretched to authorize the definition of liability standards by the executive branch.

205. 467 U.S. 837 (1984).

206. Id. at $842-43$.

207. Id. at 843 .

208. Id. The EPA specifically rclied on Cheyron's holding in proinulgating the Ruling. Under Chevron, "where there is ambiguity in the statute, the Congress has implicitly invited the appropriate regulatory agency to clarify [the ambiguityl through legislative rulcmaking." Hearing on H.R. 4494, supra note 53, at 51 (statcinent of James M. Strock, EPA).

Several courts recently faced with deciding the degrce of deference to be granted to the EPA in interpreting CERCLA have ruled in favor of the EPA. See, e.g., Wagner Seed Co. v. Bush, 946 F.2d 918 (D.C. Cir. 1991), petition for cert. filed, 60 U.S.L.W. 3537 (U.S. Jan. 13, 1992) (No. 91-1140); Fertilizer Inst. v. EPA, 935 F.2d 1303 (D.C. Cir. 1991). These eases, however, involved simple interpretations of the statutory langnage and in no way resemble the massive rulemaking effort and complete reversal of policy present in the immediate controversy.

209. For application of Chevron deference analysis, compare EEOC v. Arabian American Oil Co. (ARAMCO), 111 S. Ct. 1227, 1236-37 (1991) (Scalia, J., concurring in part and concurring in the judgment) with Rust v. Sullivan, 111 S. Ct. 1759,1769 (1991). Chevron deference is more likely to be granted when the subject matter of an administrative rule is technically complex, and therefore is peculiarly within the administering agency's expertise. See, e.g., Aluminum Co. of America v. Central Lincoln Peoples' Util. Dist., 467 U.S. 380, 389-90 (1984) (acknowledging administrator's reasonable interpretation of statute regarding contracts for the supply of electric power); Chevron, 467 U.S. at 859-64 (1984) (discussing definition of stationary sources of pollution in industry). Such is not the case with lender liability. Indced, the determination sounds like a simple policy issuewhom to hold liable and for what. In the EPA's own words: "This proposed rule seeks to reconcile a security holder's need to manage, oversee, or to otherwise act to protect a security interest, with 
The timetable under which the Ruling was initially proposed may weigh against any deferential treatment by the courts: ${ }^{210}$ the Ruling was hastily proposed under the threatened political pressure of both congressional adjournment deadlines ${ }^{211}$ and impending federal legislation. ${ }^{212}$ This pressure led to the EPA's almost overniglit reversal of policy. ${ }^{213}$

The effect of the Ruling on private reimbursement and contribution actions is also problematic. Altliough the EPA announced that it would conform to the Ruling, even if not adopted, private party actions miglit not be governed by the EPA's interpretation of the exemption's language even if the Ruling were adopted. ${ }^{214}$

EPA's duty to clean up waste sites and recover public funds spent in remediating these sites from those responsible or otherwise involved in the facility's operations . . ." EPA Proposed Ruling, 56 Fed. Reg. at 28,800 .

It is not even clear that the Ruling would be analyzed under Chevron, since in $A R A M C O$ the majority analyzed the issue under Skidmore v. Swift \& Co., 323 U.S. 134 (1944). In Skidmore, the Court stated that the weight to be given to an agency's interpretation of its organic statute's language would depend on, among other things, its consistency with earher and later pronouncements. $I d$. at 140. The consistency factor has been apphied in inore recent cases to determine that an agency's interpretation deserves little or no deference when in conflict with the agency's previous, long-held views. See, e.g., General Elec. Co. v. Gilbert, 429 U.S. 125, 143 (1976); NLRB v. Bell Aerospace Co., 416 U.S. 267 (1974). The EPA has not been consistent in its interpretation of the exeinption. In Fleet Factors, the EPA urged the court "to adopt a narrow and strictly literal interpretation of the exemption that excludes from its protection any secured creditor that participates in any manner in the management of a facility." United States v. Fleet Factors Corp., 901 F.2d 1550, 1556 (11th Cir. 1990), cert. denied, 111 S. Ct. 752 (1991). The Ruling represents a complete reversal of this policy. See supra note 161 and accompanying text.

210. In Portland Cement Ass'n v. Ruckelshaus, 486 F.2d 375 (D.C. Cir. 1973), cert. denied, 417 U.S. 375 (1974), the court noted that "[a]t least part of the deference assigned to administrative construction of a statute, concerns the passage of time under which the agency view has become an accepted interpretation and in which the Congress has not acted to nullify the agency practice." Id. at 383 n.31.

211. The EPA Ruling came in response to the furor surrounding the Fleet Factors decision in May of 1990. See Amy D. Marcus \& Ellen J. Pollock, EPA Plans Rule to Curb Liability on Loans to Owners of Waste Sites, WALL ST. J., Feb. 14, 1991, at B4. Although the EPA initially argued that the Eleventh Circuit's language concerning a lender's management activities was merely dicta, and therefore had no binding precedent, see EPA Draft Says Creditors Using Standard Cleanup Practices Exempt from Liability, 56 Banking Rep. (BNA) No. 8, at 333 (Feb. 25, 1991), the EPA nevertheless promised a congressional panel holding hearings on Superfund lender hability that an agency ruling would be forthcoming. See Hearing on H.R. 4494, supra note 53, at 38 (statement of James M. Strock, EPA).

212. See infra notes $217-54$ and accompanying text.

213. For a different perspective on the weight to be given to this reversal of policy, see Peter $L$. Strauss, Comment: Legal Process and Judges in the Real World, 12 CARDozo L. REV. 1653, 165657 (1991) (arguing that agencies are free to treat statutes as they desire, and courts have less power to enforce standards of rcasoned judgment).

214. Many players in the lender liability arena consider the Ruling ineffective in private actions. See, e.g., Hearing on H.R. 4494, supra note 53, at 89 (statement of Edward L. Yingling, American Bankers Association); id. at 107 (statement of James P. O'Brien).

The EPA, however, feels that there is no need for legislation, and that courts will give weight to the EPA's policy. The EPA specifically cites Wickland Oil Terminals v. Asarco, Inc., 792 F.2d 887, 
Because courts' reactions are somewhat unpredictable, lenders are still faced with the unknown quantity of CERCLA liability and the illdefined scope of the exemption. It is therefore not surprising that, rather than relying on the Ruling, many lenders are calling for congressional action $^{215}$ to provide a substantial fix to CERCLA. ${ }^{216}$

\section{LEGISLATIVE RESPONSES TO JUDICIAL INTERPRETATIONS OF THE SECURED CREDITOR EXEMPTION}

One commentator notes that "[w] hile environmental laws articulate some of society's noblest values and aspirations, their structure more closely resembles a shack on Tobacco Road than a Gothic cathedral."217 Although there are obvious problems with simply accepting the EPA pronouncement of how the language contained in the secured creditor exemption should be read, turning to Congress for a quick fix to patch the problematic "shack" does not necessarily represent the best alternative. Indeed, choosing the appropriate remedial measures to respond effectively to the problem is a task that needs to be undertaken with great care. Otherwise, the solution may provide yet more uncertainty, and merely recast the concerns of the already troubled lending community.

A balance must be struck between lenders' financial role and their role in ensuring environmental safety and compliance. It is important that this balance provide lenders with the ability to protect their financial interests. Strict, clear guidelines are needed to define when a lender will and will not incur hability under CERCLA for its actions. At the saine time, CERCLA must be sufficiently flexible to insure that investors are not able to shelter themselves from liability by taking on the appearance of a lender.

891 (9th Cir. 1986), in which the court accorded "very great deference" to EPA's interpretation of the statute even though the case constituted an entirely private-party action, as standing for the idea that the interpretive ruling will be accorded deference even in third-party actions. See Hearing on H.R. 4494, supra note 53, at 51 (statement of James M. Strock, EPA); see also Hawaiian Elec. Co. v. EPA, 723 F.2d 1440, 1447 (9th Cir. 1984). But see B.F. Goodrich Co. v. Murtha, 754 F. Supp. 960, 967 (D. Conn. 1991) ("[EPA's] policy is a guide to EPA employees in administering the Superfund and reflects EPA priorities. ... It does not limit a private party's claims.").

215. See, e.g., Dennis Krumholz \& Kathleen West, EPA Proposes to Allay Lending Uncertainties, 129 N.J. L.J., Oct. 24, 1991, at 55, 81.

216. At a minimum, Congress should explicitly endorse the EPA's position that the agency has autliority to issue such a ruling.

217. Robert V. Percival et al., Environmental Regulation: Law, Science and PolICX (forthcoming 1992) ("No part matclies any other part, and there are loles here and there. Still, it provides a measure of basic slelter, and there comes a point where it is easier to tack a new board over a gap that appears than to redesigu the entire structure." (quoting Ronald Outen, Environmental Pollution Laws and the Architecture of Tobacco Road, in NATIONAL RESEARCH Council, MULtimedia Approaches to Pollution Control: A Symposium Proceedings 139 (1987))). 
In an effort to address these issues, Congress has been and still is considering several bills to clarify the exemption's ambiguity. Representative John J. LaFalce has been at the forefront of congressional efforts to himit the liability of financial institutions under CERCLA. As Cliairman of the House Committee on Small Business, Representative LaFalce heard tales of the consequences of lenders abandoning specific industries, and of small businesses being unable to secure the necessary financing required to continue everyday operations. ${ }^{218}$

On Marcl 14, 1991, Representative LaFalce introduced H.R. 1450,219 a revamped version of H.R. 4494, an earlier bill, that "makes it clear that a lender inay take proper and prudent actions during a workout to prepare a property for sale or preserve its value witlout fearing unlimited Superfund liability."220

218. A good example is found in the statennent of Lee Schroeder, President of the First National Bank in Dana, Indiana (population 800):

With the recent surge of court decisions on environmental hability, our bank has had to carefully consider what types of businesses in Dana could present hability problems. Soine of the businesses ... that could be affected by possible environmental problems are the community's ouly auto body shop and convenience store which is also the ouly place where you can buy gas in Dana. (The other service station closed because of environmental probleins and cannot be reopened because it cannot get financing.).... [T] here are ouly two auto repair places in the community and our bank does business with both. There is also only one fuel dealer .... and we have loaned on the property where the bulk storage is done: financed and secured by that property.

Hearing on the Impact of Superfund Lender Liability on Small Businesses and Their Lenders Before the House Comm. on Small Business, 101st Cong., 2d Sess. 43 (1990). The bank was concerned that it might have to cease lending to these businesses because environmental liability for cleanup of any of the properties could wipe out the bank's capital-a disaster for the small community.

219. H.R. 1450, 102d Cong., 1st Sess. (1991). As of March 3, 1992, the bill had 266 co-sponsors. Upon introduction of H.R. 4494, 101st Cong., 2d Sess. (1990), on April 4, 1990, Representative LaFalce indicated that it was designed to reverse Maryland Bank. He stated that the bill would exempt lenders from CERCLA hability for merely foreclosing on the contamimated property im order to "restore the law to the way Congress originally intended it [to be]," thereby preventing the growing squeeze on small businesses from reaching "horrendous proportions." Hearing on H.R. 4494 , supra note 53 , at 14 .

H.R. 4494, refining an earlier bill, was the subject of extensive hearings before the Subcommittee on Transportation and Hazardous Materials of the House Committee on Energy and Commerce. Concerns about the proposed legislation were voiced by several witnesses in hearings before the committee. See, e.g., Hearing on H.R. 4494, supra note 53, at 22 (comments of James C. McDonald and James C. Mauch, Environmental Audit, Inc.) ("Exempting an entire class of potentially responsible parties from the hability provisions eviscerates this important goal, and in effect it throws the baby out with the bath water."); see also Kate McKerma, StATE News Service (Sept. 6, 1990) (Ralph Nader, joining forces with, among others, the Sierra Club, the NRDC and the New York Public Interest Research Group, hkened H.R. 4494 to the savings and loan "tragedy."). Unfortunately, as had been the case with Representative LaFalce's previous effort, the second session of the 101st Congress expired without final passage of the bill. This failure, however, allowed Representative LaFalce time to respond to the Fleet Factors decision.

220. 56 Banking Rep. (BNA) No. 12, at 546 (Mar. 25, 1991) (reporting comments of Rep. LaFalce). 
Specifically, H.R. 1450 amends the definition of "owner or operator" found in section 101(20) of CERCLA ${ }^{221}$ and parallels the Ruling's definitions of the terms "indicia of ownership," "participating in the management," and "primarily to protect [the] security niterest."222 Even with the bill's proposals, however, the exemption would reniain unclear: "Participatimg in the managennent" is ambiguously defined as the "actual, direct, and continual or recurrent exercise of managerial control ... which ... materially divests the borrower, debtor or obligor of such control."223 This language suffers from the same uncertainty as did the second draft of the Ruling: It leaves unclear what amount of control by the lender constitutes "material" divestiture of control,224 and whether control over one aspect of the facility waives the exeinption for all other aspects of the facility, especially when the lender is concerned only with protecting its security interest and not with participating in the day-today operating decisions regarding the environmental policies of the facility. ${ }^{225}$

Regarding the definition of "primarily to protect [the] security interest," the bill states that once a lender has acquired title, the lender nay continue to avail itself of the exemption's language as long as he "diligently is proceeding to sell or convey title ... on coniniercially reasonable terms at the earhiest possible time while preserving the property in the interim."226 Yet, definitions of "diligence," "commercially reasonable," and "earliest possible time" are absent from the bill..227

The bill provides no direction to lenders as to the balance that should be drawn between gaining commercially reasonable terms for the transaction and transferring the property at the earliest possible time. For example, it is unclear whether a lender can wait until it is able to

221. See H.R. 1450, § 1(a).

222. Criticism that the bill grants "blanket immumity" to lending institutions is unfounded because the bill specifically defines the exemption as not available to a lender who "causes or exacerbates a release or threatened release of a hazardous substance." Id.

223. Id.

224. See supra note 178.

225. The language of proposed CERCLA $\S 101(20)(E)$ (vi) addresses potential liability, but not in the participation in inanagement context: A person "causing or exacerbating" a release "shall be liable for the cost of such response, to the extent that the release ... is attributable to the person's activities." H.R. 1450, $\$ 1(\mathrm{a})$. Therefore, even without participating in the nnanagement of a facility, a lender may nevertheless be held liable, but only for the harm immediately attributable to its actions, and not jointly and severally for the whole cleanup cost.

226. Id.

227. Representative LaFalce was undoubtedly influenced by the EPA Ruling in using these terms. See Lender Liability Under Hazardous Waste Laws: Hearings Before the Subcomm. on Policy Research and Insurance of the House Comm. on Banking, Finance and Urban Affairs, 102d Cong., 1st Sess. 4 (1991) [hereinafter Hazardous Waste Hearing] (statement of Rep. LaFalce). 
recoup all of its loan investment before transferring title, even though it could dispose of the property sooner, but for less money.

H.R. 1450 also places importance on the presence of an environmental audit:228

Completion of an environmental imspection ... consistent with good commercial or customary practice by or for the use of a security holder is probative evidence that the security holder is acting to preserve and protect the ... facility during the time the security holder may have possession or control of such ... f facility. 229

This language places an affirmative yet ambiguous duty on the lender to procure an environmental audit. The prerequisites for such a duty, however, are already specified within the context of the innocent landowner defense. ${ }^{230}$ Nevertheless, the absence of an inspection would arguably be evidence that suggests behavior inconsistent with the spirit of the bill.

As with the Ruling, the bill fails to address whether the immunity enjoyed by the lender under the exemption is transferrable to a subsequent purchaser. ${ }^{231}$ Finally, although the bill permits lenders limited control over their borrowers without incurring liability, it fails to resolve adequately the disharmony between lenders' conflicting roles in controlling financial and environmental risk.

S. 651,232 an effort by Republican Senator Jake Garn of Utah to address the problem, adopted a different approach than that of LaFalce's bills. The original text of the bill, found in S. 2319,233 stated that its purpose was "to protect the deposit insurance funds, to hmit the liability of depository institutions, credit unions, and other mortgage lenders acquiring real property through foreclosure or similar means, or in a fiduciary capacity, and for other purposes." 234 S. 651 was originally proposed

228. This provision substitutes for the innocent landowner defense by prohibiting the transfer of property without first ensuring the environmental condition of that property. See supra note 23 .

229. H.R. 1450, § 1(a).

230. See supra note 23.

231. See supra note 191 and accompanying text. For other problems hampering passage of the bill, see Hearing on H.R. 4494, supra note 53, at 50-51.

232. S. $651,102 d$ Cong., 1st Sess. (1991). S. 651 reintroduced in substantially the same form S. 2319, 101st Cong., 2d Sess. (1990), also sponsored by Senator Garn, which was originally introduced on March 22, 1990. S. 651 was originally introduced on March 13, 1991, and was subsequently absorbed into the Comprehensive Deposit Insurance Reforn \& Taxpayer Protection Act, $\mathrm{S}$. 543, 102d Cong., 1st Sess. (1991). Specifically, with a few minor changes, S. 651 was imcorporated as Title X, entitled the Asset Conservation and Deposit Insurance Protection Act of 1991. See id. $\S 1001$. Upon revision of the act, Title $\mathrm{X}$ was changed to incorporate an amendment to CERCLA along with the proposed amendment to the FDIA. When S. 543 was finally signed into law on January 3, 1992, Title $X$ had been excised from the legislation as part of a compromise between the House and the Senate. See Federal Deposit Insurance Corporation Improvement Act of 1991, Pub.

L. No. 102-242, 105 Stat. 2236.

233. S. 2319, 101st Cong., 2d Sess. (1990).

234. Id. at 1. 
to address the lender hability problem by emphasizing amendment of the Federal Deposit Insurance Act, ${ }^{235}$ which governs lender transactions, rather than significantly amendimg CERCLA. ${ }^{236}$ With the bill's incorporation into Title $\mathrm{X}$ of S. $543^{237}$ and further modification therein, however, the final proposal was to amend significantly both the FDIA ${ }^{238}$ and CERCLA. ${ }^{239}$ Among its major provisions, Title $\mathrm{X}$ would have himited the hability under CERCLA or other applicable federal laws of an "insured depositary institution" or a "mortgage lender" when holding property because of foreclosure, a fiduciary capacity, or the extension of credit, to "the actual benefit conferred on such institution by a removal, remedial, or other response action undertaken by another party."240 The bill would have held a lender hable only for any increase in value of the property (not to exceed the fair market value of the property241) due to any response action undertaken by "another party," presumably the EPA. ${ }^{242}$ The exceptions to this hability limit are listed, and mclude "any person that has caused or contributed to the release of a hazardous substance;" any person who "fail[s] to take reasonable steps to prevent the continued release of a hazardous substance" 243 once property has been acquired, provided that such a release is "discovered"; and any person who "has caused or significantly contributed to the release" of a substance. ${ }^{244}$

The bill specifically came to the aid of "Federal banking or lending agenc[ies],"245 including, but not limited, to the FDIC and the RTC, both of which are threatened with potentially massive hability under current interpretations of the CERCLA liability provisions. ${ }^{246}$ Title $\mathrm{X}$ also

235. 12 U.S.C. $\S \S 1811-1832$ (1988).

236. The only proposed amendments to CERCLA were those necessary to conform CERCLA to the proposed amendments to the FDIA. See S. 651, § 171 (1991).

237. S. 543, 102d Cong., 1st Sess. (1991) (enacted as modified as Federal Deposit Insurance Corporation Improvement Act of 1991, Pub. L. No. 102-242, 105 Stat. 2236).

238. See S. 543, § 1002(a) (Oct. 4, 1991-Version 2) [hereinafter S. 543 (Oct. 4)]; S. 543, $\S 1002$ (b) (Nov. 26, 1991-Version 4) [hereinafter S. 543 (Nov. 26)] (proposing FDIA § 42).

239. See S. 543 (Nov. 26), § 1002(a) (proposing CERCLA § 127).

240. Id. (proposing CERCLA § 127(a)(1)).

241. See id. (proposing CERCLA $\S 127(b)$ ).

242. See id. (proposing CERCLA § 127(a)(1)).

243. The bill does not define or otherwise give any guidance as to what is and what is not to be considered "reasonable" under the circumstances, although Title $\mathbf{X}$ is an improvement over H.R. 1450 in that it defines most of the terms used. See id. (proposing CERCLA $\S 127(\mathrm{e})$ ); id. § 1002(b) (proposing FDIA § 42(d)).

244. Id. \$1002(a) (proposing CERCLA § 127(c)); cf. S. 543 (Oct. 4), § 1002(a) (proposing FDIA $\S 42(c)$ ) ("any person that actively directs or conducts operations that result in the release of a hazardous substance. ...").

245. S. 543 (Nov. 26), § 1002(b) (proposing FDIA $\S 42(d)$ ).

246. Under CERCLA § 101(35)(A)(ii), 42 U.S.C. $\S 9601$ (35)(A)(ii), a governmental entity is not liablc if it acquires the facility in an involuntary transfer or acquisition. On its face, this provision 
addressed the issue of transfer of immunity to a subsequent purchaser of the property, but only under certain limited circunistances: The purchaser nuust be the first in time after the acquisition, must not otherwise be hable because of a past relationship with the property, must not be "affiliated with"247 or related to a hable party, and must not fail to take reasonable steps to prevent a continued release. ${ }^{248}$ The gravamen of the subsequent purchaser protection, however, is that the purchaser must buy froin a federal banking or lending agency. ${ }^{249}$ This provision addressed the concern that the federal agencies involved in bailing out banks could potentially be unable to transfer the properties acquired, but ignored that other lenders are faced with the same problen of benig unable to realize the true value of a property once foreclosure has taken place. In some cases, this disparity in treatnient may create financial incentives for the earlier takeover of failing institutions by the RTC.

One of the niajor problems with the protection of the subsequent purchaser provision is that Title $\mathrm{X}$ also included a clause that saved all state law causes of action. ${ }^{250}$ If state law is not preenipted, then it is unclear whether state regulations governing and restricting the transfer of property will affect the conveyances that the subsequent purchaser protection is supposed to encourage. ${ }^{251}$

In connection with the subsequent purchaser provision in the final version of Title $X$, before it was eliminated from S. 543, the bill required that if response to a spill was required by a federal or state agency because of the subsequent purchaser's failure to take reasonable steps to prevent any further release, then the subsequent purchaser would have to reimburse the agency for the response costs. However, reimbursement

would apply to the FDIC and the RTC. However, there is a great deal of uncertainty about whether the two entities would actually be completely protected, because the corporations play many different roles im performing their duties. See Hearing on H.R. 4494, supra note 53, at 70-73 (memorandum provided by FDIC and RTC on uncertainty of the defense for governmental entities). For a failed attempt to protect federal governmental entities from liability due to involuntary transfers by amending CERCLA $\S 101(20)(A)(i i i)$, see H.R. 4076, 101st Cong., 2d Sess. (1990) (Rep. Silvio Conte, sponsor).

247. See supra notes 59-64 and accompanying text.

248. S. 543 (Nov. 26), $\S 1002$ (a) (proposing FDIA $\S 42(a)(4)$ ).

249. Id. FDIC Chairman L. William Seidman has stated in connection with this provision that the bill's exemptions are "essential for the cost-effective operation of the FDIC and the RTC. The bill would better enable [the corporations] to sell properties by removing the specter of superfund liability . . ." 56 Banking Rep. (BNA) No. 12, at 546 (Mar. 25, 1991) (letter from L. William Seidman to Senator Jake Garn (Mar. 19, 1991)).

250. See S. 543 (Nov. 26), § 1002(b) (proposing FDIA § 42(a)(2)).

251. See Margaret Murphy, The Impact of "Superfund" and Other Environmental Statutes on Commercial Lending and Investment Activities, 41 BuS. LAw. 1133, 1161-63 (1986). 
would have been limited to the full fair market value of the property following the remedial action. ${ }^{252}$

Title X of S. 543 also contained a provision that limited liability under any state law to the "value of the agency's interest in the asset giving rise to such liability."253 Although this was a compromise between the federal concern for lender liability on the one hand, and the states' concern for protectimg their own backyards through application of state CERCLAs on the other, this compromise ouly applied to governmental institutions and not to private entities. Title $\mathrm{X}$ also provided safe liarbors for botll governmental and mortgage lenders, and in doing so addressed the Fleet Factors decision by explicitly stating that liability would not be based on an "unexercised capacity to influence operations" of the facility constituting the security interest. 254

\section{A Proposal for LeNDer Liability UNDER CERCLA}

Two competimg policy considerations pervade judicial and executive resolutions of lender hability issues under CERCLA: to promote a lender's economic role by removing barriers to lending, and to provide mcentives for lenders to play an environmental role by influencing borrowers to promote safe handling of hazardous substances. The conflict between these two roles is an unnecessary consequence of judicial and EPA interpretations of the secured creditor exemption. As we demonstrate below, only Congress can minimize this conflict.

A lender's economic role is to facilitate commerce by providing a readily available source of financing for new and existing enterprises. In fulfilling this role, lenders, guided by state liability standards, have developed practices to evaluate, monitor, and control the prospects and policies of their debtors. ${ }^{25 s}$ These practices minimize the financial risk

252. See S. 543 (Nov. 26), § 1002(b) (proposing FDIA § 42(a)(5)). Garn's proposed legislation does not generally limit the lender's liability to the amount of the loan, however. Contra Stephen Kleege, Ruling Stirs Friends of Lender Liability Bill, AM. BANKER, June 7, 1990, at 2, 15 (claiming S. 2319 linited liability to the amount of the loan).

253. S. 543 (Nov. 26), §1002(b) (proposing FDIA § 42(a)(2)).

254. See id. $\$ 1002$ (a) (proposing CERCLA $\S 127$ (a)(2)).

255. See Tom, supra note 113, at 934-43 (proposing a standard of liability based on coinmon law theories); see also Robert H. Shadur, Emerging Trends in Lender Liability, CBA REC., Jan. 1990, at 16,20 (stating that courts examine the control exerted by the lender over the borrower's business-a traditional examination in control cases). See generally Helen D. Chartman, The LaW op LENDER LiABILITY (1990); LENDER LiabilitTy: Definitions, Theories, APPLICATIONS (Dennis M. Patterson ed., 1990); EDWARD F. MANNino, LENDER Liability aND Banking Litigation (1991); William N. Medlock, Comment, Stemming the Tide of Lender Liability: Judicial and Legislative Reactions, 67 DENV. U. L. REV. 453 (1990). 
associated with a loan. Yet because enterprise and innovation are inhibited by external controls, and because lender participation in a borrower's affairs can create environmental liability, lenders generally participate at a level below that necessary to minimize perceived financial risk.

When lenders are induced to play an environmental role through enhanced CERCLA hability, it is assumed that they will be able to adjust their control mechanisms to effectively perform this role. This assumption has proven to be ill-founded, particularly when applied to lenders that provide funds to small businesses and to industries with significant environmental risk. ${ }^{256}$ Enhanced CERCLA hability places lenders in a tug of war between common law and CERCLA liability standards: Common law permits lenders to reduce environmental and financial risks by policing the activities of borrowers, thereby protecting the value of their collateral, while CERCLA discourages such behavior through imposition of liability. This conflict creates disorder in an area of the law where order and certainty are highly valued, creating a potential for the enhancement, ratler than the minimization, of environinental and economic costs.

The Petroleum Marketers Association of America (PMAA), in testimony on CERCLA lender liability before the House Committee on Small Business, ${ }^{257}$ provided a real-world example of the consequences of broad and uncertain environmental liability standards and the conflict between the roles of insurers and lenders acting as insurers. ${ }^{258}$ PMAA's

256. Commentators and recent testimony before congressional subcommittees addressing CERCLA lender liability suggest that lenders are engaging in avoidance behavior. See Hazardous Waste Hearing, supra note 227, at 472 (preliminary results of an ABA survey shows $88 \%$ of responding community banks have changed their behavior in response to enhanced environmental liability, including "a reluctance to lend to those businesses which want to protect or restore the condition of the environment"). One explanation of this surrender of viable inarkets by lenders is lenders' inability to assess the risk associated with hazardous waste liability. Rational lenders would refuse loans where the probability that they will incur significant environmental liability cannot be adequately offset through the terms of the loan. Yet distressed institutions, those willing to take gambles more stable firms would not take, actually have an incentive to act irrationally.

257. See Small Business Hearing, supra note 3, at 123-31 (statement of L.W. Locke, PMAA).

258. This conflict suggests that fixing environmental hability upon insurers can be problematic because insurers may refuse to insure. See id. at 17 (noting that survey of the PMAA found that 26,500 stations may close as a result of EPA regulations. "Over 86 percent are in population centers of less than 50,000 persons. Clearly, rural areas will bear the primary brunt of these regulations."). Yet lenders should exercise similar prudence and refuse to lend in situations where the risk of environmental liability is too great. Tom, supra note 113, at 933, ignores this point, arguing instead that lenders are better monitors than insurers: "[T]nsurance companies can be effective monitors because they spread risks through premiums and are experts in collecting and evaluating information about the insured. Insurance for environmental liability, however, is expensive and difficult to obtain." The expense associated with insurance, however, is a direct result of the difficulty in collecting and evaluating, whether done by the insurer or lender. Lenders should, therefore, be particularly wary of 
example involved RCRA, 259 but because RCRA contains its own secured creditor exemption, its lesson is equally helpful when applied in the CERCLA context.

Under RCRA, tank owners inust provide evidence of financial responsibility (i.e., insurance). ${ }^{260}$ But, because of the high risk of insuring the tanks, insurance is issued only after tanks are repaired or replaced. Because of the potential for substantial RCRA liability associated with underground storage tanks, however, lenders will not provide funds to owners to improve their facilities without adequate insurance. The unfortunate result is the closing of beneficial businesses, the abandonment of deteriorating underground tanks that could eventually cause environmental damage, and the misallocation of resources-instead of repairing old tanks, resources are devoted to the building of new stations on clean sites. ${ }^{261}$

The PMAA's testimony illustrates that the free availability of funds is critical to the continuity of business operations, and demonstrates that increased lender hability, under CERCLA or RCRA, will not necessarily lead to environmental quality. In the case of petroleum inarketers, enhanced hability eliminates funds necessary for the proper maintenance and replacement of capital stock required to correct and prevent hazardous conditions.

RCRA's provisions addressing the petroleum industry demonstrate a potentially useful partitioning of financial and environinental responsibility: The lender mamtains its role in minimizing its debtor's financial risk, while the insurer assumes the role of minimizing environmental risk. This plan failed in practice, as is evident from the illustration above, because of the threat that courts would impose extended RCRA hability upon lenders (paralleling decisions under the secured creditor exemption), thereby making it impossible for owners to obtain insurance.

To resolve the dilemma in the context of CERCLA, Congress need only restore its original intent to exempt lenders when they act as lenders

loans when insurance is unavailable. Under this Note's proposal, this problem is minimized by reducing uncertainty as to the amount of insurance required. See infra text accompanying note 276. When the industry is too risky to insure, or information is too difficult to obtain, the solution must turn not on who is liable, but on whether the government is willing to subsidize the problem industry's activity.

259. 42 U.S.C. § 6991b(h)(9); supra note 5. The PMAA sought to expand H.R. 4494 to protect their industry under section $6991 \mathrm{~b}$.

260. 42 U.S.C \& 6991b(d).

261. See Small Business Hearing, supra note 3, at 15 (statement of L.W. Locke, PMAA) ("If this isn't a catch-22 situation, I don't know what is."). 
and, therefore, to exclude from liability lenders who have ownership status merely to protect their security interests. ${ }^{262}$ With this approach, the lender (assuming the lender is not an operator or true owner) by not foreclosing can limit its loss to the value of its collateral. With this clarification, lenders would be free to provide funds to restore the facility to an environmentally responsible state, and insurers would then be willing to insure the operation of the facility. The environment is also served: The facility is restored to a safe condition, and both the lender and the insurer are positioned to ensure future compliance and to provide necessary funds if such precautions fail.

The SBA, also testifying before the House Committee on Sinall Business, described another problem created by enhanced lender liability. Before CERCLA, lenders played a central role in the development of new enterprises by providing financial and managerial advice, influx of new capital, and assistance in moiritoring and controlling the practices of infant enterprises. New small businesses are, however, inherently highrisk enterprises. ${ }^{263}$ The imposition of unrestrained CERCLA hability imposes upon lenders potential costs far in excess of the foreseeable benefits froin lending to sinall businesses. The result has been a diminished availability of funds for sinall businesses. ${ }^{264}$

The Eleventh Circuit, in United States v. Fleet Factors Corp. ${ }^{265}$ attempted to respond to this dilemina. Lenders, the court inaintained,

262. Such an approach does not relieve a lender from CERCLA liability; it merely places lenders on an equal footing with other PRPs. By limiting liability to the value of the secured lender's collateral, a lender would also be able to insure, if desired, the value of the collateral against potential environmental costs, instead of needing to insure against the indeterminate costs of full CERCLA liability.

263. The active role lenders play in the formation and operation of these enterprises is a direct response to this risk. See Small Business Hearing, supra note 3, at 13 (statement of Charles Mitsclow of the Small Business Banking Committee, American Bankers Association) (stating that the failure rate of small businesses is already high, reaching $60 \%$ over a five-year life cycle. The additional weiglit of environmental liability can be unbearable, resulting in banks refusing to lend to certain types of small businesses.).

264. See id. at 29-30 (statement of Sally B. Narey) ("[S]ome otherwise credit-worthy small businesses may simply not be able to bear the costs of ligher periodic loan payments and, as a result, may not be able to afford financing."). Furthermore, fearing liability for participating in the day-today operations of a facility, lenders may refuse to offer advice to inexperienced small businesses. Id. At the same time, the difficulty in obtaining funds can cause small firms to act irrationally, and as a result be less responsive to environmental concerns. Although not discussing environmental concerns, for a real-world example of a firm taking seeuningly illogical steps when financially impaired, see Leonard M. Apcar \& Caleb Solomon, Going for Broke: Hunt Brothers Pin Hopes for Comeback on "Crapshoot" in Oil, WALL ST. J., July 12, 1988, at 1.

265. 901 F.2d 1550 (11th Cir. 1990), cert. denied, 111 S. Ct. 752 (1991). 
could impose a risk premium based on the risk associated with the borrower's environmental activities. ${ }^{266}$ This risk premium, in effect, is insurance on the potential costs of CERCLA cleanups associated with the facility. ${ }^{267}$ As such, the preminm's cost is independent of the amount of the loan. In fact, if properly valued, the environmental risk premium would often require absurd imterest rates on small busmess loans. Further, if the facility desires multiple lenders, each lender, to protect itself, would need to assess mdependently the environmental risk and charge the risk premium, thereby creating needless redundancy. ${ }^{268}$

This analysis demonstrates that the interest rate charged by a lender can be viewed as having two mam elements: a premium associated with financial risk and an insurance premium associated with environmental risk. ${ }^{269}$ The total risk associated with a loan is not, however, a straightforward calculus. Rather, the assessment of both risks depends on the level of involvement the lender expects to assert over the borrower's management practices. Through active mvolvement, the magnitude of both environmental and business costs can be diminished. At the same timie, however, involvement increases the likelihood that the lender will be found liable for environmental costs. As a result, lenders must choose

266. See id. at 1558.

267. Others argue that, by himiting lender liability, the EPA becomes the insurer of the lender's security interest. Some courts, such as the Fleet Factors court, have concluded that if lenders are exempt from hability upon foreclosure, the lender will be able to purchase the secured property at a bargain and then sell the property after it is cleaned up by the government. See id. at 1559 (An expansive interpretation of permissible participation "would convert CERCLA into an insurance scheme for financial institutions, protecting them against possible losses due to the security of loans with polluted properties.") (citations omitted). Yet federal and state liens are specifically designed to allow government agencies to recapture value added to the facility if sufficient funds are not found from PRPs. Because the relative strength of these liens was specified by Congress when it passed CERCLA, it is difficult to formulate an argument to support the judicial enrichment of these liens. See supra note 128.

Iromically, a lender that does not foreclose maintains a lien on the property superior to federal liens and ean capture the full benefit of the land's value if it is able to forestall foreclosure until the cleanup is finished. At the same time, if a lender that is found not to be a PRP forecloses on a facility, the lender can lose its security interest if a federal or state lien attaches to the property.

268. Because of the perceived increase in liability in the wake of the Fleet Factors decision, "more lenders may require Phase II audits (soil and water sampling) in situations where a Phase I audit (site visit and paperwork review) would be adequate." Bolstein \& Reznick, supra note 93, at 3.

269. Malloy, supra note 154 , at 70 :

[T] he lender looks upon the making of loans as the investment of funds in return for interest payments which, over the expected life of the loan, provide a competitive rate of return relative to other investment opportunities available to the lender. The interest rate charged by the lender has to provide the market rate of return for the use of money-the real rate of return -and, in addition, be sufficiently high to cover the rate of inflation expected to occur over the life of the loan. 
a level of activity that does not minimize both financial and environmental risks, but rather that reaches a compromise to minimize the lender's total risk. ${ }^{270}$

CERCLA addresses this problem in its treatment of loan guarantors by limiting the guarantor's liability to the amount guaranteed. 271 Guarantors constitute a class of PRPs who exhibit many of the same characteristics and capacities to influence hazardous waste disposal as lenders. 272 Both lenders and guarantors, at a minimum, risk the principle amount in a transaction and botlı have incentives to momitor borrowers to insure that environmental aspects-and all other aspects of the business-are appropriately handled by the borrower. The basic distinction between lenders and guarantors is that lenders often hold indicia of ownership, whereas guarantors do not. As a result, lenders are threatened with disproportionate liability, whereas guarantors' liability is limited to that amount for which they certify financial responsibility, as long as they act in good faitli. ${ }^{273}$

Congress, unlike tlie judiciary and the executive (which are limited by CERCLA's current language), has the power to create an appropriate lender liability standard. It is essential tliat Congress address the need to balance lenders' dual roles. A compromise needs to be reached, and both the EPA Ruling and the recent congressional efforts go a long way toward suggesting the solution. However, it is evident that further congressional action is needed.

To create an appropriate balance, Congress needs to restore the original intent of the secured creditor exemption (i.e., the title/lien theory). This would rejuvenate the distinction between true lenders, and investors who act as lenders inerely to gam the exemption's protection.

270. See supra note 117.

271. CERCLA § 108(d), 42 U.S.C. § 9608(d); id. § 101(13), 42 U.S.C. § 9601(13) (defining "guarantor" as "any person, other than the owner or operator, who provides evidence of financial responsibility for an owner or operator ....").

272. Id. For example, insurers, who fall within CERCLA's definition of guarantors, see supra note 271 , consider similar risk characteristics of facilities. See S. REP. No. 848, 96th Cong., 2d Sess. 93, 121 (1980), reprinted in 1 LEgisLATIVE HisTORY of CERCLA, supra note 29, at 400, 428:

The availability of insurance is particularly crucial to small and medium-sized busimesses.

However, insurance availability is largely dependent on developing the probabilities of the conditions under which payments would be made. Once these probabilities are defined, the availability, the coverage and the cost of insurance can be established. Thus, the analysis of both asset exposure and insurance availability largely hinges on the predictability of habilId. ity for a specific decision.

273. See 126 Cong. REc. 26,204 (1980), reprinted in 2 Legislative History of CERCLA, supra note 29, at 924-25 (comments of Rep. Snyder of Kentucky on H.R. 85, as amended by Rep. Mario Biaggi of New York). The House recognized that uncertainty would make guarantors reluctant to provide insurance to owners and operators. See 126 CONG. REC. 26,374 (1980), reprinted in 2 LegisLATIVE History OF CERCLA, supra note 29, at 964. 
Limited participation, even participation in hazardous waste inanagement, would be permissible under this theory (as long as it does not rise to the level of operator liability). Courts would still be able to interpret the exemption, but would be constrained by the clarified language.

In addition to the varying interpretations of "participation," the exeinption failed because it did not address the protection of lenders upon foreclosure. Two inechanisnis exist which would, if initiated, permit a lender to capture any residual value left in a contaminated site after factoring in uncollectible cleanup costs: (1) expanding federal liens so that they are superior to secured loans-i.e., creating a federal superlien;274 and (2) creating specific provisions under which lenders could seek preforeclosure settleinents with the EPA. ${ }^{275}$ Under the first approach, prudent lenders would only foreclose on a contaminated site if the expected cost of the cleanup was less than the value of the facility. Under the second approach, the EPA would be able to control, on a case-by-case basis, the disposition of a contaminated site but at higher adıninistrative costs.

This two-pronged approach permits lenders to promote proper business practices by their borrowers. At the same tinie, a third party, such as an insurer, would be able to price and provide a control mechanisin for environmental risk. 276 In this way, both financial and environmental risks can be effectively minimized-lenders would be free to act to reduce environmental and financial risk to collateral, while insurers would be free to protect against the firm's overall environmental risk, 277 and allow lenders to insure just the value of their collateral. As applied to current

274. See supra note 128.

275. See CERCLA $\S 122,42$ U.S.C. $\$ 9622$ (settlement provisions); Guidance on Landowner Liability Under Section 107(a)(1) of CERCLA, De Minimis Settlements Under Section 122(g)(1)(B) of CERCLA, and Settlements with Prospective Purchasers of Contaminated Property, 54 Fed. Reg. 34,235 (Aug. 18, 1989); Michele B. Corash \& Lawrence Behrendt, Lender Liability Under CERCLA: Search for a Safe Harbor, 43 Sw. L.J. 863, 875 n.84, 878-88 (1990) (analyzing the EPA Guidance).

276. There are practical reasons to involve insurance companies. Insurance companies are better positioned to choose whether to accept specific environmental risks and to later refuse to insurc. They can choose which particular aspects of a transaction they want to insure, and can insulate themselves from more risky undertakings-a much more fine-tuned practice than that available to lenders. Insurers are also more experienced im evaluating environmental risk-and often declime to insure otherwise viable enterprises. This choice is not available to lenders. Although covenants can be used to provide lenders with some ability to escape a poorly positioned loan, such contraetual clauses are often unenforceable, particularly if the borrower is in receivership. As a result, when a lender enters into a transaction, it must shoulder all associated risks for the duration of the loan. A lender must also modify its practices to reduce environmental risk. Thus, not only is the lender limited to a "to lend or not to lend" decision, but also the lender must be willing to accept enhanced financial risk as it modifies its busmess practices to minimize environmental risk.

277. CERCLA already provides a means to require financial responsibility. CERCLA "recommends" that the President turn to the insurance industry to help determine appropriate levels of responsibility. See CERCLA $\S 108(b)(2), 42$ U.S.C. $\S 9608(b)(2)$. 
lenders who hold security interests in contaminated property, most notably the RTC and FDIC, this approach would greatly reduce, although not eliminate, potential hability while providing sufficient certainty to permit prudent decisionmaking.

\section{CONCLUSION}

There are significant benefits to providing a clearly defined national rule of CERCLA lender hability. To do otherwise restricts the availability of funds to American industry and creates the potential for disparity in the imposition of environmental costs and habilities on lenders among the judicial circuits. For example, the Ninth and Eleventh Circuits have formulated dramatically different constructions of the secured creditor exemption. The Ninth Circuit decision would make lending less costly and less risky. On the other hand, the Eleventh Circuit decision, as a practical matter, would eliminate the protection provided by the secured creditor exeinption. Neither, however, provides a comprehensive approach to minimizing lenders' financial and environmental risks. The uncertainty of the law itself adds an extra level of risk, and therefore cost, to each loan.

The approach adopted by the EPA Proposed Ruling instills three additional sources of uncertainty. First, there is significant uncertainty with respect to the deference courts will grant to the Ruling in EPA and private reimbursement actions. Second, the ainbiguous state of the exemption diminished the ability of the EPA to provide a certain rule. Lenders cannot, therefore, rely on the Ruhing in determining their proper course of action. Third, since the EPA is free to change the Ruling at a later date, the Ruling is susceptible to political pressures.

The pro-lender decisions and the Ruling will not be effective in minimizing lenders' uncertainty. The unpredictability of lender liability decisions, and the possibility of new, retroactively-apphed standards, compels lenders to address the higher liability standards. Lenders miglit seek a imiddle ground between two different standards based on the relative probabilities of mcurring each form of liability. ${ }^{278}$ Even this middle ground, however, diminishes lenders' ability to protect their security imterests, resulting in higher costs of financing - costs avoidable, however, througli appropriate legislation. In today's fragile financial world, with its failing savings and loans and banks and its tightening supply of new capital, leaving lenders defenseless to intervene in a creditor's business practices has had, and will continue to have, grave consequences. In

278. See PoSNER, supra note 117 , at 512 . 
fact, in dealing with high environmental risk and small business enterprises, lenders have only two choices: to loan funds knowmg that they will risk full CERCLA hability if they take active steps to protect their interests; or not to loan to mdustries which have higher environmental risks, but which may be essential to America's economy. Only Congress can "bring certainty back into commercial practices"279 and at the same time provide an effective environmental solution.

279. See Petition for Certiorari of Fleet Factors Corp. at 5, Fleet Factors (No. 90-504). 